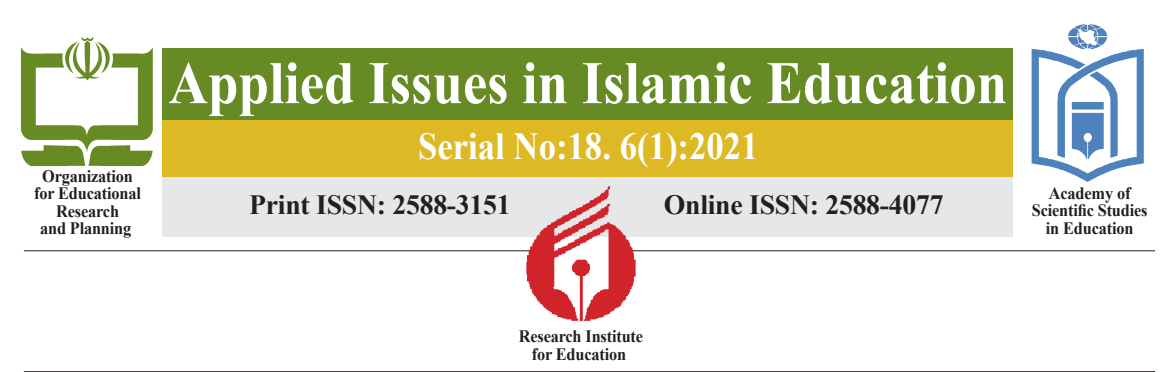

\title{
Designing an Optimal Pattern for Religious Education Curriculum at a Preschool
}

-Zeinab Ashrafi Soltan-Ahmadi ${ }^{1}$ "Javad Keyhan ${ }^{2}=$ Sadegh Maleki Avarsin $^{3} \backsim$ Jahangir Yari $^{4}$

Objective: The main purpose of this study was to design an optimal model for the religious education curriculum at a preschool.

- Method: In terms of objective, the present study is an applied one that has been done by qualitative method and through research synthesis.

The statistical population consisted of all the domestic research related to the subject matter in the period of 1379 (SH) to 1399 (SH) and 1999 to 2019, and from among them, 49 (including 38 domestic and 11 foreign) studies as the samples were selected purposefully, and analyzed through the Roberts six-step model.

- Findings: The main finding of this study was to make a proposal for the religious education curriculum at a preschool. The proposal consisted of 10 elements based on the Akker's approach.

- Conclusion: In the religious education of preschool children, all the aspects of a young learner's existence must be considered with a holistic approach. The ultimate goal is flourishing the nature and good life of a child, and it can be achieved through the intermediate and behavioral goals of a young learner. The educational content should be based on religious teachings and educational objectives, and it should be provided for a learner through a teaching-learning activity appropriate to the interests and developmental needs of the children by an educator with moral, religious and professional competencies. The educator should mainly play a model and guidance role, and accelerate the flourishing of religious nature in children. The instructional materials should be varied, and selected as a package. An instructional space should have happy liviely facilities for play, and stimulate children's curiosity. Evaluation should be a process and carried out using various tools such as behavior observation, workbook and parental opinion.

Keywords: religious education, peschool, research synthesis, curriculum

Citation: Zeinab Ashrafi Soltan-Ahmadi, Javad Keyhan, Sadegh Maleki Avarsin, Jahangir Yari.(2021). Designing an Optimal Pattern for Religious Education Curriculum at a Preschool, Applied Isuues in islamic Education, 6(1): 7-30

Received: $2021 / 02 / 28$

Accepted: 2021/05/23

1. A Ph.D. student in Curriculum, the Department of Educational Sciences, Tabriz Branch, Islamic Azad University, Tabriz, Iran.

E-mail: ashrafizeinab81@gmail.com. (iD) 0000-0001-6910-5052

2. Corresponding Author : An Assistant Professor, Department of Educational Sciences, Urmia Branch, Islamic Azad University, Urmia, Iran.

E-mail: keyhan.edu@gmail.com. (iD) 0000-0001-6022-9702

3. An Associate Professor, Department of Educational Sciences, Faculty of Human Sciences, Tabriz Branch, Islamic Azad University, Tabriz, Iran.

E-mail: s.maleki@iaut.ac.ir. (D) 0000-0003-3841-8333

4. An Assistant Professor, Department of Educational Sciences, Tabriz Branch, Islamic Azad University, Tabriz, Iran.

E-mail: john_yari@yahoo.com. (D) 0000-0002-3215-4931 


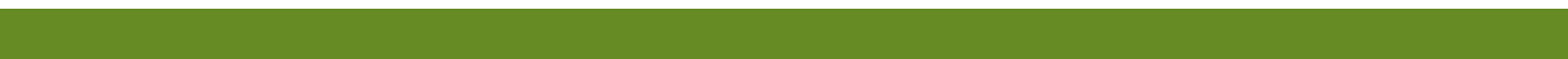



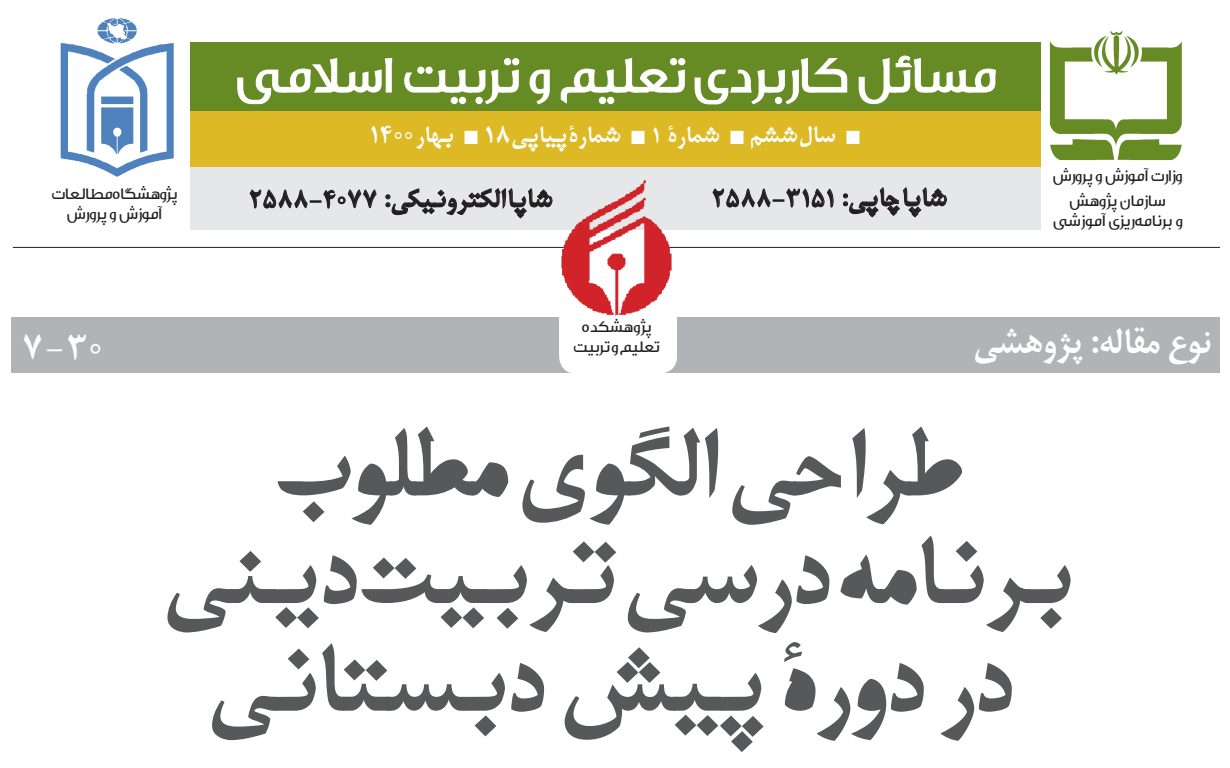

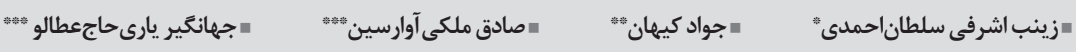

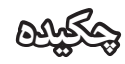

ه هدف: هدف اصلى تحقيق حاضر، طراحى الكوى مطلوب برناملدرسى تربيتدينى در دوره بيش دبستانى بوده است.

• روش: يزوهش حاضر از نظر هدف، كاربردى است كه بلروش كيفى و با استفاده از سنتزئز

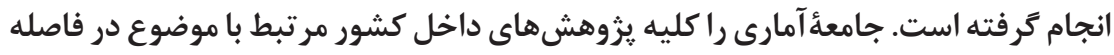

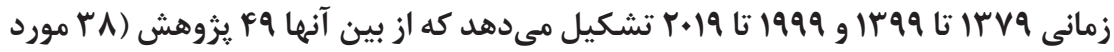

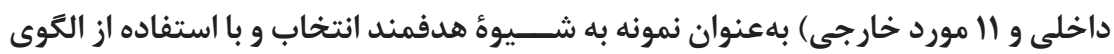
شش مرحلهاى روبر تس مور دبر رسى قرار كرفتند.

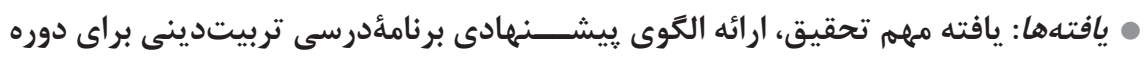

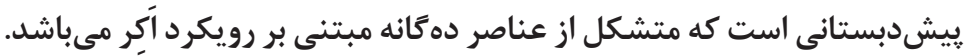

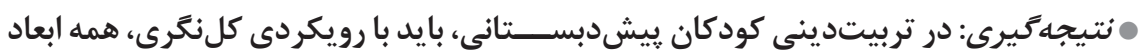

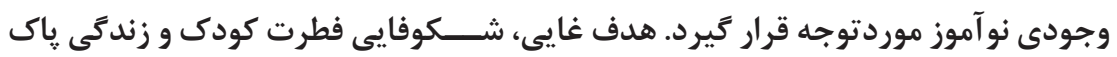

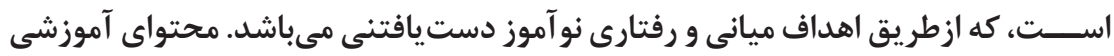
H

* دانشجوى دكترى برنامهريزى درسى، واحد تبريز، دانشعاه آزاد اسلامى، تبريز، ايران. E-mail: ashrafizeinab81@gmail.com. (ID 0000-0002-6910-5052

**** نويسنده مسئول: استادياركروه علومتربيتى، واحد اروميه، دانشعاه آزاد اسلامى، اروميه، ايران.

E-mail: keyhan.edu @gmail.com. (iD 0000-0001-6022-9702

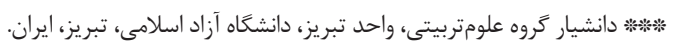
E-mail: maleki@iaut.ac.ir. (iD) 0000-0003-3841-8333

E-mail: john_yari@yahoo.com. (D) 0000-0002-3215-4931

. 
بايد مبتنى بر آموزههاى دينى و اهداف آموزشــــى بــــوده و ازطريق فعاليتهاى تدريس -

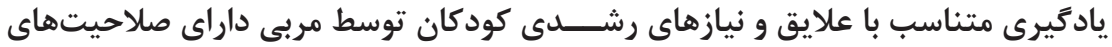

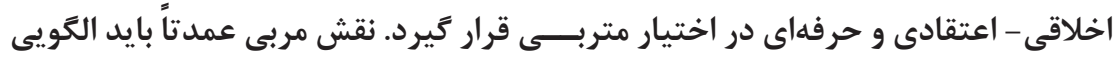

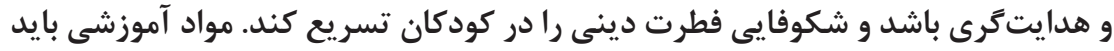

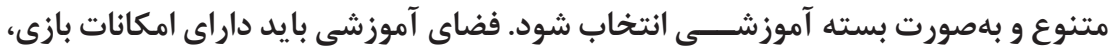

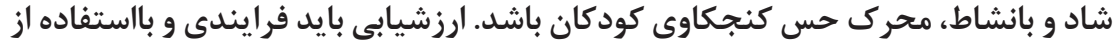

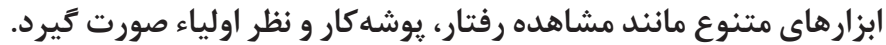

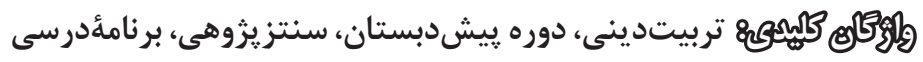

مقدمه

استقرار نخرش جامع توحيدى در متربى و تنظيهم جهت گيرى او بهسوى خدا همواره يكى از مهممترين دغدغههاى ييامآوران الهى و مربيان تربيتدينى بوده و هست (بقرها سع|): و خداى شما، خداوند يعانهاى است كه غير از او معبودى نيست! اوست بخشنده و مهربان! رهايى از حيطه كثرتهاى وهمى و در آمدن به وادى وحدت و يخانگى و سيراب شدن در آبشخور زلال توحيد، هدف نهايى تربيت توحيدى است. اخرجه آدمى با فطرتى

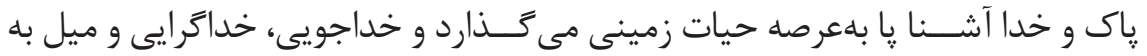
يرســتش آن وجود بـهمتا از مصاديق فطرى است كه ازجانب خداوند متعال در وجود هر انســانى بلهوديعه نماده شده اســت، اما بهتدريج غبار فراموشى بر آن شناخت فطرى نشسته و از سوى ديخر، برخى از اسلوبها و شيوههاى تربيتى از جمله تحميل و تلقين نيز بهجاى صيقل اين آينه الهى، خود حجابى بر آن شــده و باعث انحراف آن مىشوند. از اينرو، زمينهســازى، يرورش، هدايت و شكوفايى فطرت توحيدى بهمنظور نيل انسان بـــهـ قله رفيع وجودى خويــش و درآمدن در مقام قرب و رضوان حضرت حق، رســالت خطير تربيت توحيدى قلمداد مىشود (قيصرى گودرزى و سلحشورى، VV II). كاركرد نظامهاى آموزشى در دوران مدرن بهعنوان نهادهاى تربيتى و فرهنًَاز فقط به انتقال بُعد دانشــى به دانش آموزان محدود نبوده و وجه هنجارين و ارزش بنيان آنها نيز مطرح

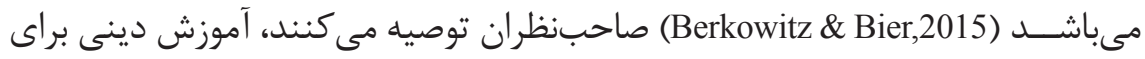


همه دانشآموزان مهمم اسـت تا بتوانند درك مفهومى از دين بيدا كرده و همدلى آنها را افزايش دهند (Jafralie \& Zaver, 2019).

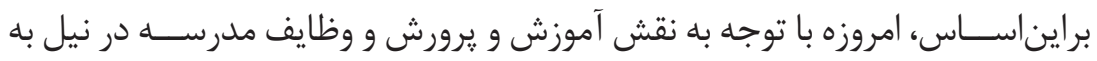

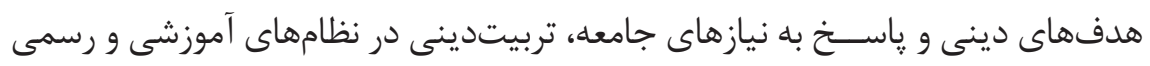

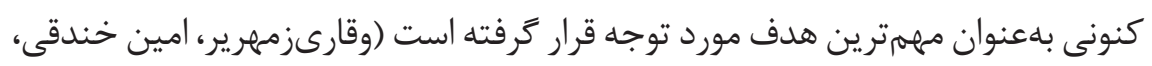

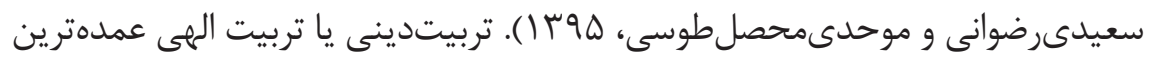
بخشمعارف اسلامى و فلسفه بعثت يِامبران و اساسىترين وظيفه اولياى الهى و متوليان

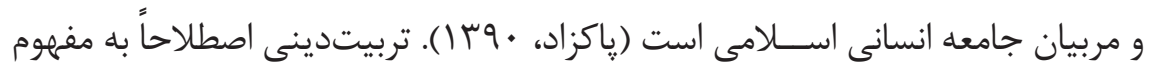

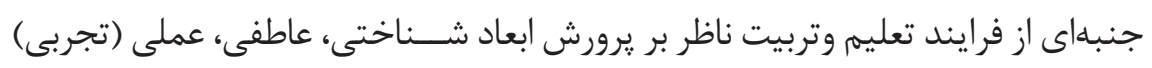

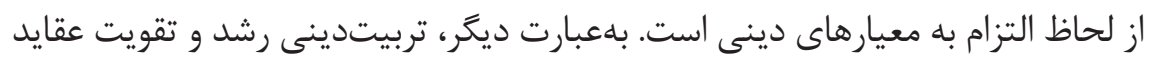

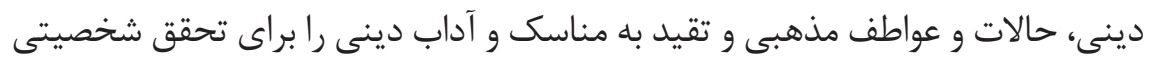

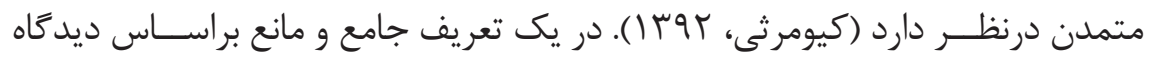

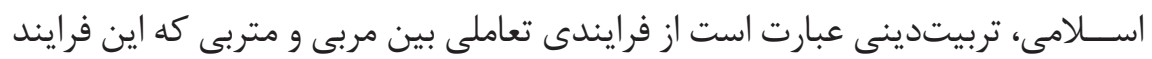

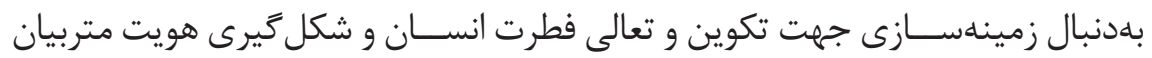

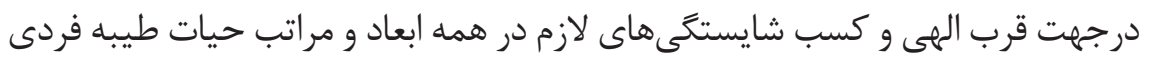

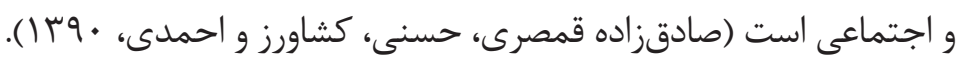

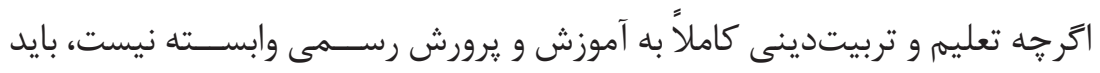

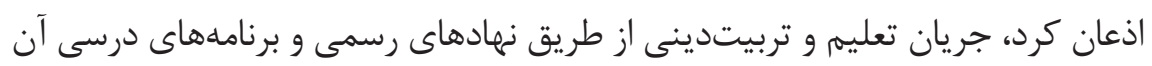

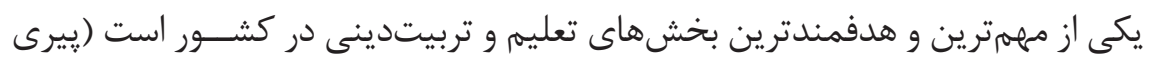

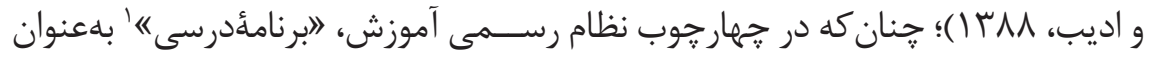

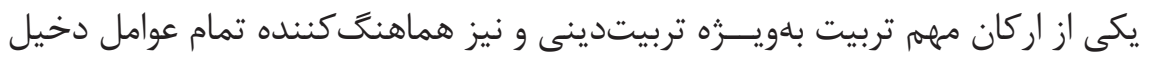

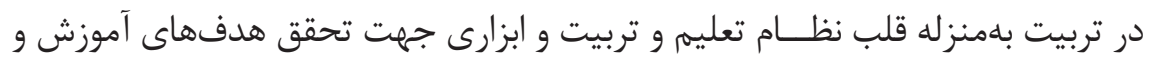

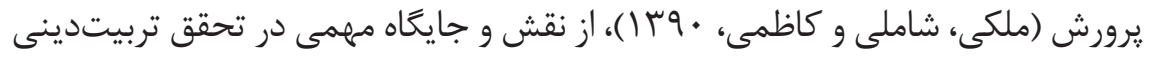

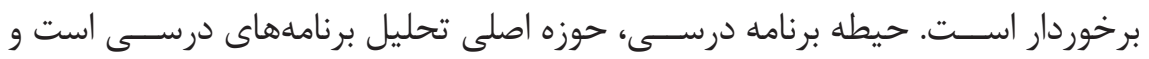

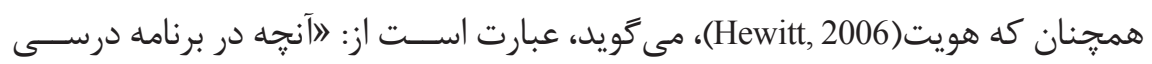

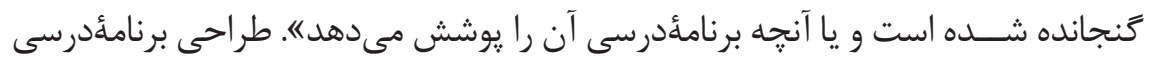


بــر اين تمركز مى كند كه جه دانش، مهارت و ارزشهايى را فراگيران بايد بياموزند؛ جهه

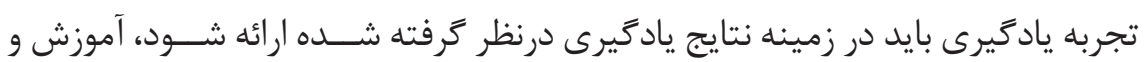
يادَيرى در سامانه آموزشــى جَكونه مىتواند برنامهريزى، اندازهگيرى و ارزشيابى شود (Aimin \& Yan, 2011). درخصــوص اينكه عناصر برنامةٔدرســى كدامند تا برمبناى آن

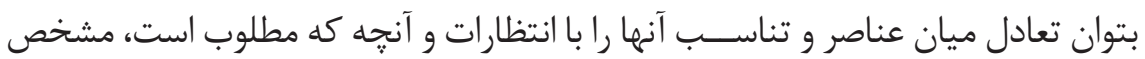
كرد، ديد Fاههاى متففاوتى عرضه شــده اســت. اما كاملترين ديد كاهها در اين خصوص،

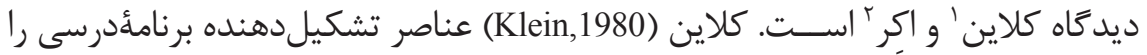
شامل: اهداف، محتوا، راهبردهاى ياددهى -يادگيرى، مواد و منابع، فعاليتهاى يادگيرى، كروهبندى، زمان و فضا و روشهاى ارزشيابى مىداند. اكر(Akker, 2003) براساس الخوى كلاين، عناصر برنامهٔدرسى را در • ا عنصر مورد توجه قرار داده است كه بهغير از عنصر

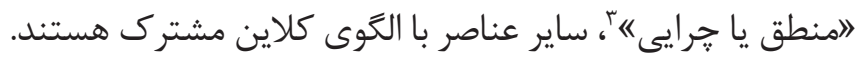
با وجود اهميت بســـيار زياد برناملُدرســى تربيتدينى در نظام آموزشــى ما، نتايج تحقيقات در مدارس نشــانكر اين اسـت كه آموزش دينى، وضعيت مطلوبى ندارد و كاه با تأثيرات معكوس نيز همراه بوده، و باعث شــده اسـت تا اين ناكارامدىها تا حد زيادى إئ در بحران آفرينى هاو كاســتىهاى رفتارهاى دينى نســل نوجوان و جوان ســـهم مؤثرى

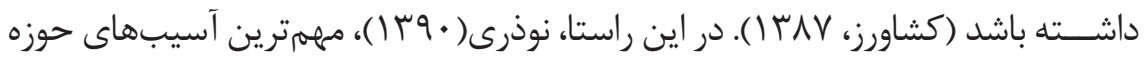
تربيتدينى را در مواردى همجون، توجه نكردن به اصل دينيابى، توجه نكردن به تجربه دينـــى فردى، دينمحور نبودن برنامه تعليهم و تربيت، رعايـت نكردن آزادى در تعليهم و تربيتدينى و رعايت نكردن ميانهروى در آموزش دينى برشــمردند. به استناد يافتههاى تحقيق آخش، حسينى خواه، عباسى و موسى يور( (ه (1)، يكى از مهمهترين آسيبهاي دوره ييشدبســتانى در ايران، عدم وجود يك برناملُدرسى مدوّن است. نتايج تحقيق بتشكن

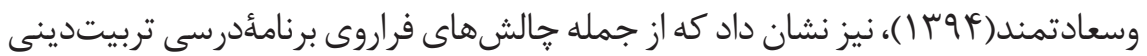
در مقطع ييش دبســانى، توجه نكردن به اصول دينيابى و تجربه دينى، توجه نكردن به اصل دين- محورى، توجه نكردن به اصل فطرت، توجه نكردن به اصل تخيل(هنر) و نيز عدم توجه به اصل آزادى و تفاوتهاى فردى است. رام، مهرمحمدى، صادقزاده قمصرى 
$v-r \circ$

و طلايى(وqس|) نيز اعتقاد دارند كه يكى از مهرمرين آســيبهاى تربيتدينى در نظام آموزش رسمى كشور، تقليل تربيتدينى به انتقال اطلاعات در حوزههاى عمدتاً اعتقادى، عبادى و عدم تخصيص ســـهم كافى به تربيت اخلاقى اســت. در همين راستا جفرالى و زاور (Jafralie \& Zaver, 2019)، در يــك مطالعه مـــوردى با عنوان اآموزش تربيتدينى

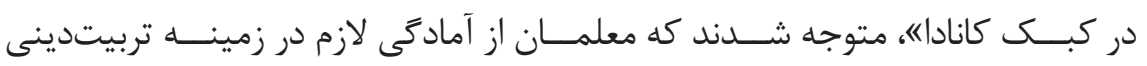
برخوردار نيســتند. درحالى كه به اعتقادكورونى لاندى، ديويس، بامفيلد، بارنز و همكاران (Conroy, Lundie, Davis, Baumfield, Barnes et-al., 2015)، معلمان عامل اصلى موفقيت بورويت

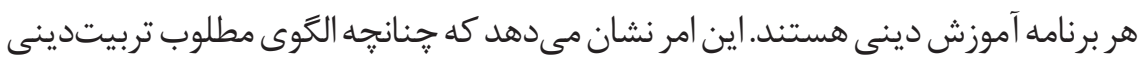
در دسترس متصديان تربيتدينى قرار نخيرد، به خطا رفتن آنها در فهمم اهداف، روشهاو محتواى تربيتدينى لطمه بسيار سنگينى به رشد دينى افراد وارد مىسازد (شمشيرى و نوذرى، • وץ (). جُنانجه تربيتدينى در قالب برنامُٔدرسى مناسب، شفاف و داراى ساختار و محتواى مطلوب و ويزه ارائه شود، مىتواند موجبات تعالى فرد و جامعه را فراهم كند.

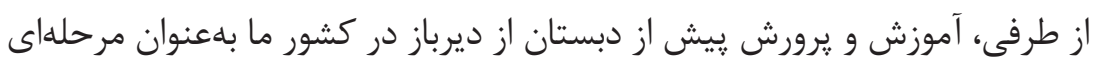
از آموزش مطرح بوده اســت و مســأله تعليمم وتربيت كودكان در اين دوره كه بايد آن را سال هاى سازندگى و تشكيلدهنده بسيارى از صفات و ويزگَى هاى كودك ناميد، از اهميت

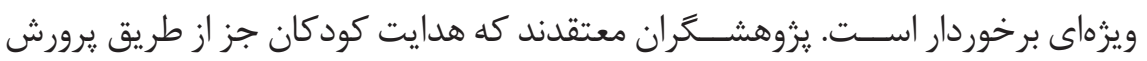
صحيح مذهبى آنان ميســـر نيســت و كودكان براى يذيرش رفتارهاى صحيح و مطلوب اجتماعى از طريق مســايل دينى، آمادگى بيشترى دارند تا از راههاى ديخر (زينال يور و

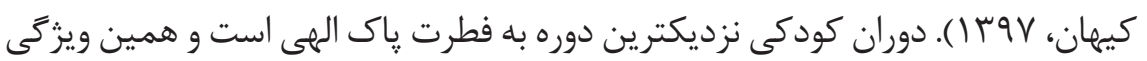
اهميت تربيتدينى در اين دوران را بيشــتر توجيه مى كند(شمشيرى و نوذرى، Vوس|). درواقع، يكى از اساســىترين ويز زى ها كه لزوم آموزش مفاهيم دينى را توجيه مى كند، وجود گرايش دينى و ميل باســـوى امور مذهبى در كودى اســت. مفاهيم اساسى دين اسلام از قبيل اعتقاد به خدا، يِيامبر (ص) و ... امورى هستند كه با سرشت او ساز گار است. بنابرايــن، اهميت اين دورهو ميزان اثر كذارى فــــاوان آن بر دورههاى بعدى بر ضرورت

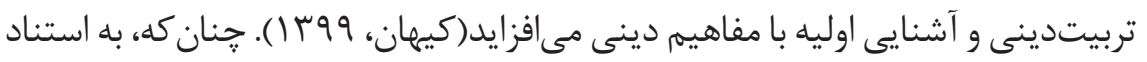

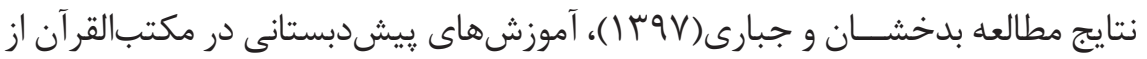
اثربخشــى معنى دارى بر روى متربيان برخوردار است. اما على غهم اهميت دوره كودكى مونى 
و شــيوه يرداختن به تربيتدينى، يزوهش هاى انجام شــده در اين حوزه بيشتر اسنادى و روايیى و مبهزم هســتند و بهصورت دقيق، الكويى را براى تربيتدينى در دوره كودكى معرفى نكردهاند. حال با توجه به خلاء تحقيقاتى موجود، سؤال اصلى تحقيق حاضر اين است كه: (الكوى مناسب برنامُٔدرسى تربيتدينى در دوره ييشدبستانى براساس نتايج

\section{مبانى نظرى}

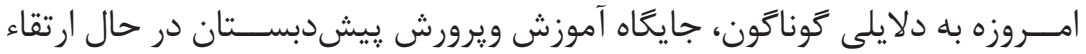
است. افزايش روزافزون متربيان، نياز جامعه و خانواده و نيز تأثير مثبت اين دوره بر كم و كيف فرايند آموزش و ياد كيرى در دورههاى بالاتر، ضرورت تدراك برنامههاى آموزشى و درسى مناسب را دوجندان كرده است(مفيدى، سوس (). تلاش و كوشش صاحبنظرانى

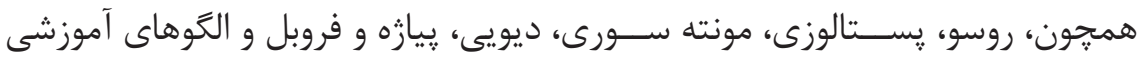

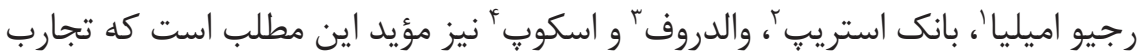

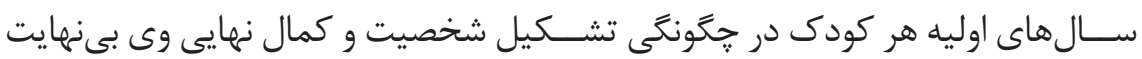

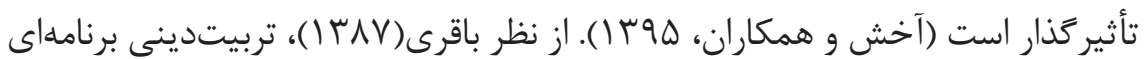
اســت كه هدف آن تقويت باورهاى دينى و التزام عملى به آموزههاى دينى و درنهايت تربيت انسانهاست. با توجه به تعاريف به عمل آمده، مىتوان اينگُونه استنباط كرد كه تربيتدينى شكوفاســازى و به فعليت رساندن جميع استعدادها در جنبههاى گوناگون شخصيتى يعنى ابعاد جسمانى، عقلانى، اجتماعى، عاطفى، اخلاقى است. اين شكوفاسازى با موازين و ضوابط المى ميســــ است و لذا خلاف جنين ضوابطى شكوفاسازى محسوب

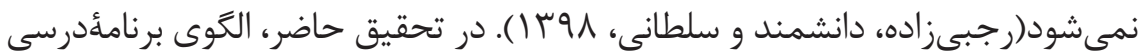
تربيتدينى ڤيشدبستانى مبتنى بر ديد Fاه اكر(Akker, 2003) مدنظر مىباشد كه شامل عناصر: منطق، هدف، محتوى، راهبردهاى ياددهى - ياد گيرى، نقش مربى، گروهبندى، مواد و منابع آموزشى، زمان، فضا و ارزشيابى بوده كه از شمول و جامعيت بيشترى نسبت 
$v-r \circ$

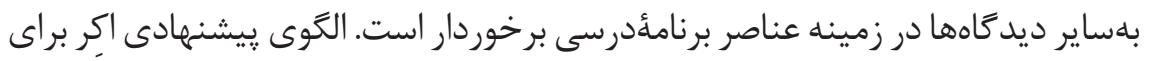
برنامئ درسـى يكى روش واضح براى به تصوير كشيدن ارتباطات بين جنبههاى مختلف در طراحى برنامه درســى است، و الگوى تارعنكبوتى ناميده مىشود. در اين الگو، همه عناصر و مؤلفهها حول محور منطق اصلى برنامdٔدرسى به يكديگر متصل و مرتبط هستند

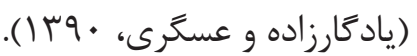

مرور ييشـــينه تحقيقاتى مرتبط با موضوع مبين آن است كه يزوهشهاى متتنوع در

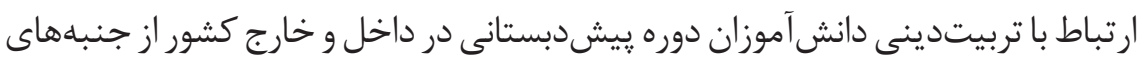
مختلف انجام گرفته اســت، كه در ادامه بهطور مختصر به برخى از آنها اشاره مىشود.

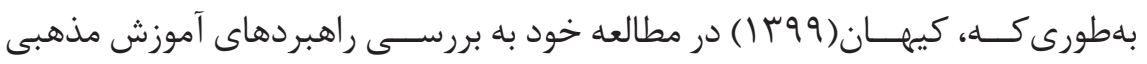
كودكان ييش دبســتانى در خانواده طى يكى يروهش آميخته يرداخت و نتيجه گرفت،

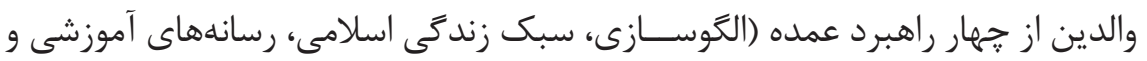
محيطها و مناســبتهاى مذهبى) براى تربيت مذهبى فرزندانشــان استفاده مى كنند. شـــريار و نجفى(1) (1) صلاحيتهاى حرفهاى مربى تربيتدينى را مورد مطالعه قرار داده و نتيجه گرفتند كه مربى تربيتدينى بايد داراى صلاحيتهاى علمى و عملى باشد.

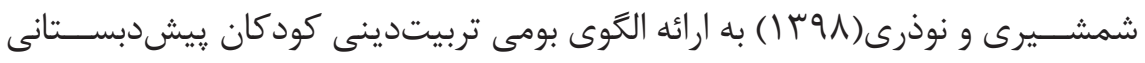
اقدام نموده و متذكر شـــند، برنامه درســى مدون و منســــمم تربيتدينى براســاس اصول و مبانى دين اســلام براى كودكان ييشدبستانى ضرورى است. راهايو و مونادى (Rahayu \& Munadi, 2019) در كودكان ييشدبسـتانى ڤيرداخته و نتيجه كرفتند كه محتواى آموزشى بايد مبتنى بر

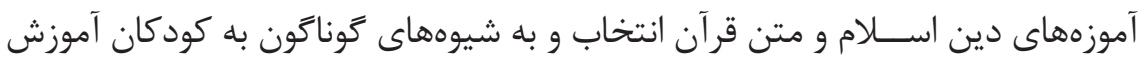
داده شود. به اســتناد نتايج تحقيقات، مىتوان ادعا كرد كه هريك از يروهشــــران از زاويه ديد خود و بهشــكل محدود تربيتدينى كودكان دوره ييشدبســتانى را مورد مطالعه قرار

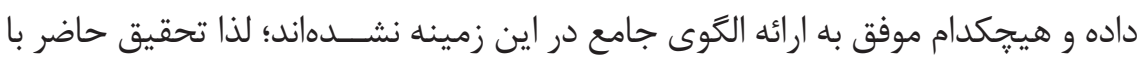
هدف طراحى الخوى منسجم برنامئدرسى تربيتدينى دوره يبيشدبستان براساس نتايج يزوهش هاى قبلى به شيوه سنتزيثوهى انجام گرفته است تا بتواند بخشى ناجيزى از خلاء 
يزوهــش حاضر از نظر هدف، كاربردى' و بهلحاظ رويكرد مورد اســتفاده، كيفى از نوع ســـتزيثزوهى "اســـ. راهبرد مورداستفاده فراتركيب اســت كه با انجام تحليل

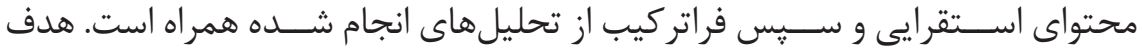

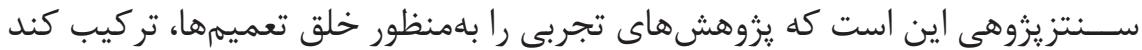

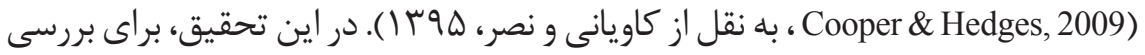
ييشينه و گردآورى دادهاى متناسب با هدف يثرهش، از مقالههاى موجود در يايخاههاى اطلاعاتى داخل و خارج كشور استفاده شده است. به اينصورت كه بامراجعه به يايعاههاى

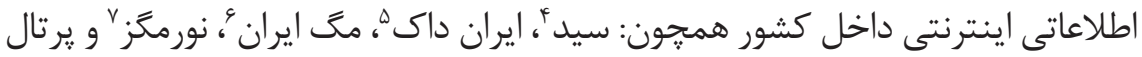
جامع علوم انسانى، سايتهاى خارج كشور نظير: اريكى، ساينس داير كتج، يروكئيست ' و ... به جســتوجو يرداخته شده و كليد وازههاى مورداستفاده شامل مفاهيمى همجون: برناملٔدرسى، تربيتدينى، دوره يِيشدبستانى، سنتزيزوهى و موارد مشابه آن بوده است. بنابراين، جامعه آمارى يثروهش را كليه مقالات علمى - يثوهشى و ياياننامههاى ارشد و

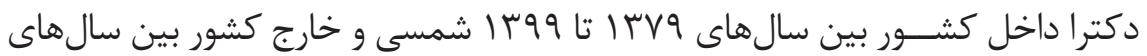
999 9 19 تا 19 • ميلادى تشكيل ميىدهد. از آنجايى كه هدف اصلى اين تحقيق، تمركز بر

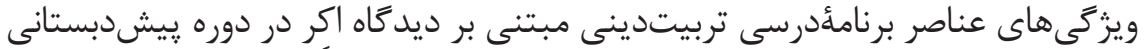

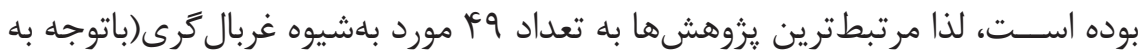
هدف يثروهش)، انتخاب و باســتفاده از الكوى شــش مرحلهاى سنتزيثوهى روبرتس " مورد تجزيه و تحليل قرار زرفتند. جدول(1) يثزوهشهاى منتخب شـــركت داده شده در يزروهش براساس مشخصات يثروهشَر، سال انتشار و موضوع (هدف) را نشان مى دهد.

1. Applied

2. Qualitative

3. Research Synthesis

4. SID.IR

5. IRANDOC

6. MAGIRAN

7. Noor Mags

8. Eric

9. Science Direct

10. Proquest

11. Roberts 


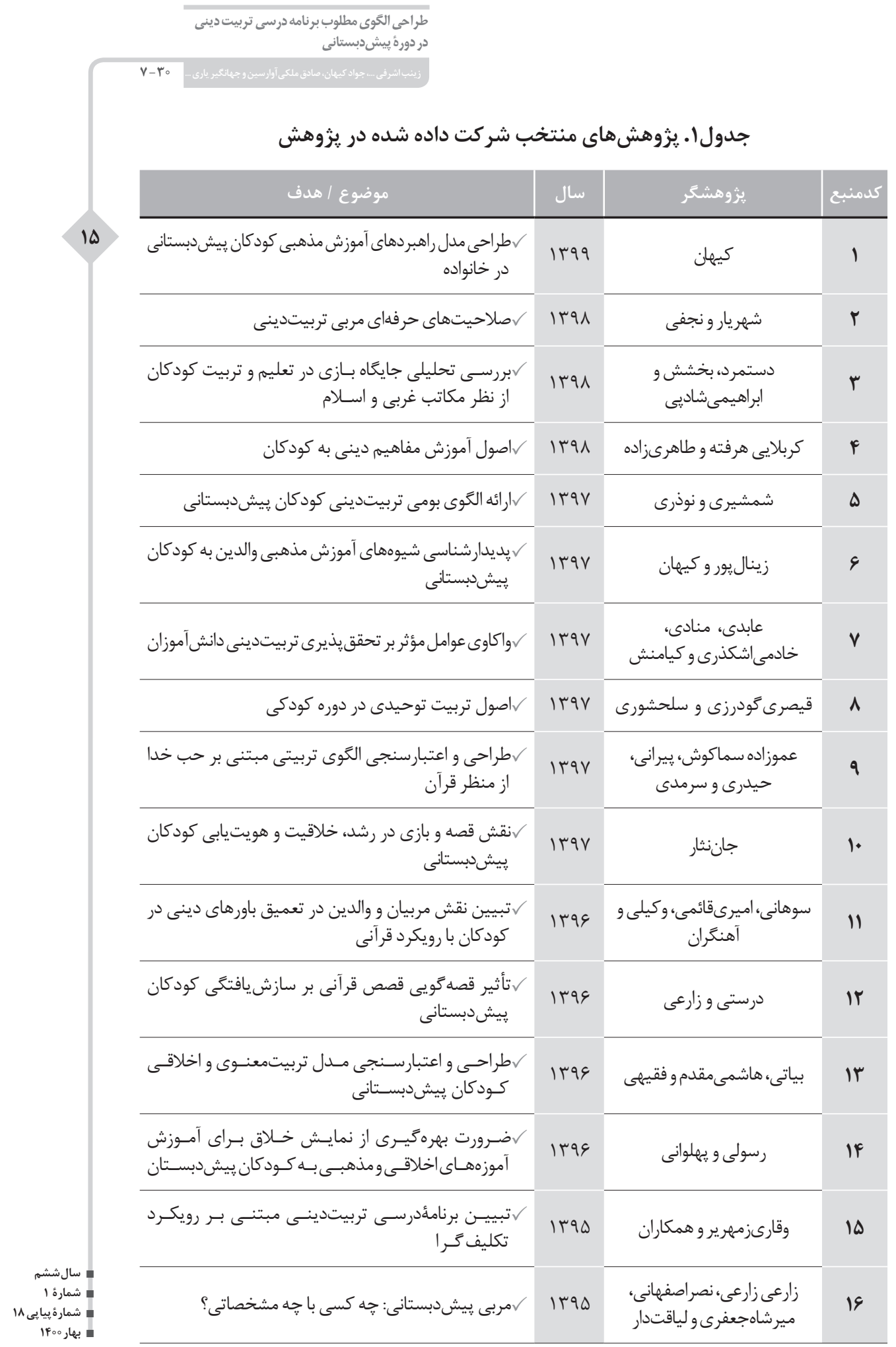


جدول ا. (ادامه)

\begin{tabular}{|c|c|c|c|}
\hline 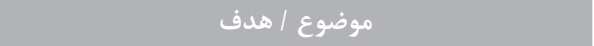 & سال & مثروهشعر & كدمنبع \\
\hline 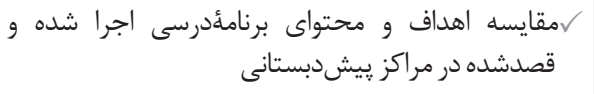 & $1 \% 9 \Delta$ & ميرزايى، احمدى و نراقىزاده & IV \\
\hline لجايحاه و نقش بازى در تربيتدينى كودكان & 1 Irq4 & 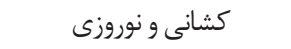 & 11 \\
\hline لحيستان انطباق برنامأدرسى قصدشده و اجراشدة پيش از & Irq4 & رضوى و گرجى يشتى & 19 \\
\hline لواسلامدى واسطى تربيت در دوران كودكى براساس رويكرد & 1 irqf & سجاديه و همكاران & r. \\
\hline \آنشنايى با ساختار تربيتدينى و راهكارهايى براى يذيرش & $1 r q 4$ & 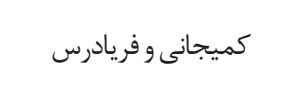 & r) \\
\hline 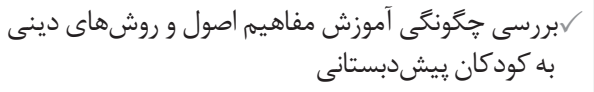 & Irqf & 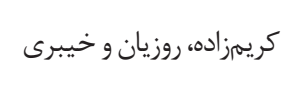 & rt \\
\hline كاهداف و روشهاى تعليم و تربيت از ديدگًاه اسلام & $1 r q 4$ & ميكائىلووسلطان القرائى & r \\
\hline طروشهاى تربيت كودى تا هفت سالكى در انديشه امام & $1 r q 4$ & رضايت و رضايت & re \\
\hline ل \بازنغرى تربيتدينى كودكان بيش دبستان & r & كريمى و سالارىجينه & ro \\
\hline لتربيتدينى كودكان ييشدبستانى & 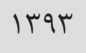 & كريميانيور و احمدى & rq \\
\hline 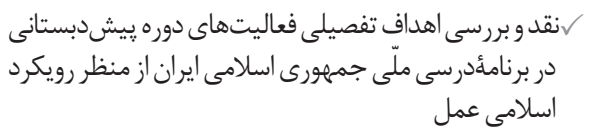 & Irat & سجاديه و آزادمنش & tr \\
\hline 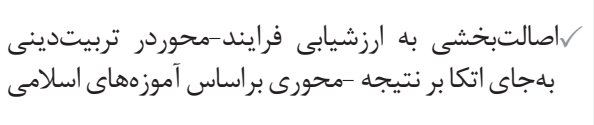 & Irat & صادقزاده قمصرىملى محصل طوسى، & r^ \\
\hline 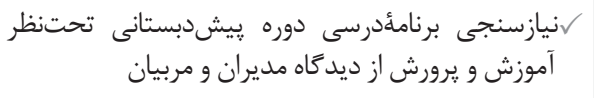 & 1491 & 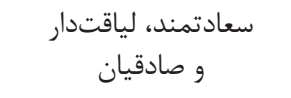 & rq \\
\hline \حالش در اهداف تربيتدينى (شناخت، عاطفه و عملكرد) & $\mid r q 1$ & عجمه سعيدىرضوانى & r. \\
\hline \تأثير تربيتى قصههاى قرآنى در تربيتدينى كودكان & $\mid r q 1$ & خلجى & ו \\
\hline 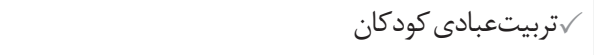 & $1 \% q$. & ملكى، شاملى و كاظمى & rt \\
\hline \آسيبشناسى تربيتدينى كودكان مقطع ييشدبستانى & $1 \% q$. & شمشيرى و نوذرى & r \\
\hline
\end{tabular}




\begin{tabular}{|c|c|c|c|c|}
\hline \multicolumn{5}{|c|}{ در دورأي يَشودى مطنانوب برنامه درسى تربيت دينى } \\
\hline & 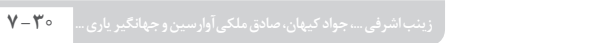 & & & \\
\hline & \multicolumn{4}{|c|}{ جدول ا. (ادامه) } \\
\hline & موضوع / هدف & 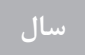 & بزوهشعر & كدمنبع \\
\hline & لتعليم و تربيت و دنياى ناشناختأ دينى كودكان & IrMA & 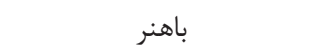 & $r f$ \\
\hline & لحالكَوى بهينه برناملٔدرسى براى دوره پيشدبستان & IrMA & ييرى و اديب & ra \\
\hline & \تربيتدينى كودكان در دوره يیشدبستانى & IrAd & تهذيبى وجوادنيا & re \\
\hline & 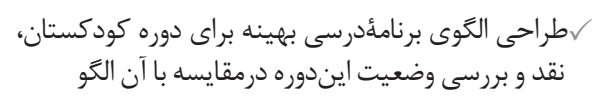 & Irat & 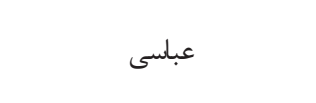 & rv \\
\hline & \تأملى درباب تناسب آموزش و يرورش با تربيتدينى & Irی. & سعيدىرضوانى وبينقى & rᄉ \\
\hline & 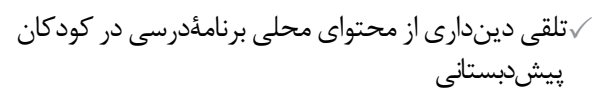 & $r \cdot 19$ & Rahayu \& Munadi & rq \\
\hline & \آموزش تربيتدينى: برنامه اخلاق و فرهنَ دينى & $r \cdot 19$ & Jafralie \& Zaver & f. \\
\hline & فرهديرَ مدرسه مذهبه براساس شخصيتسازى در زمينه & $r \cdot 1 \Lambda$ & Marini, Safitri \& Muda & p) \\
\hline & \نقش والدين در تربيتدينى و اجتماعى كودكان & $r \cdot 1 \Lambda$ & Aran \& Nayebkabir & Fr \\
\hline & \انديشههاى غزالى در برنامٔدرسى معارف اسلامى & $r \cdot I V$ & Barni \& Mahdany & pr \\
\hline & لهالشهاى اجراى مؤثر برنامأدرسى مطالعات دينى & $r \cdot 10$ & Njoku \& Njoku & FF \\
\hline & آموزي اريى اهداف برنامأدرسى يِيشدبستانى تركيه ازنظر & $r \cdot I f$ & Duman & FD \\
\hline & \آموزش تربيتدينى كودكان در مقدونيه امروز & $r \cdot 11$ & $\begin{array}{c}\text { Mirascievaa, Petrovskia \& } \\
\text { Gjorgjeva }\end{array}$ & pq \\
\hline & تجارب اندونزى دئى مالزى اسلامى در كشورهاى مسلمان: & $r \cdots \Lambda$ & Hashim \& Langgulung & pV \\
\hline & 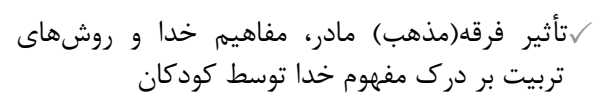 & $r \cdot r$ & $\begin{array}{l}\text { DE roos, Iedema \& } \\
\text { Miedema }\end{array}$ & iA \\
\hline 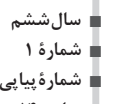 & شرويكرد جامع آموزش اسلام به كودكان: مطالعه موردى & $r \cdots r$ & Lemu & $p q$ \\
\hline
\end{tabular}




\section{يافتلهاى تحقيق}

يس از استخراج و يالايش يايههاى نظرى و مضامين اصلى دادهها از منابع مورد استفاده،

كدگذارى محورى با مرتب كردن، درآميختن و سازماندهى انبوهى از دادهها انجام گرفت.

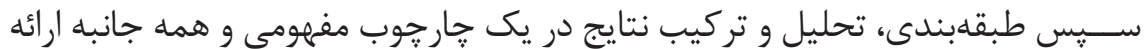
شد. براى اطمينان از اينكه تمامى مفاهيهم مورد اشاره استخراج شدهاند، جندينبار از ابتدا تا انتها همه عبارتها و جملات موردبررسى مجدد قرار گرفت و مفاهيمم مشابه دستهبندى و درســطح انتزاعىتر در قالب يك مقوله كلى قرار داده شدند. بر اين اساس، جدول (r)، خلاصه نتايــج فرايند كدَذارى باز جهت اســتخراج ويزگى هاى عنصر برناملُدرســى تربيتدينى دانشآموزان ييشدبستانى را نشان مىدهد.

جدول r. خلاصه نتايج كدَذارى باز و استخراج ويزگى هاى عناصر برناملدرسى تربيتدينى

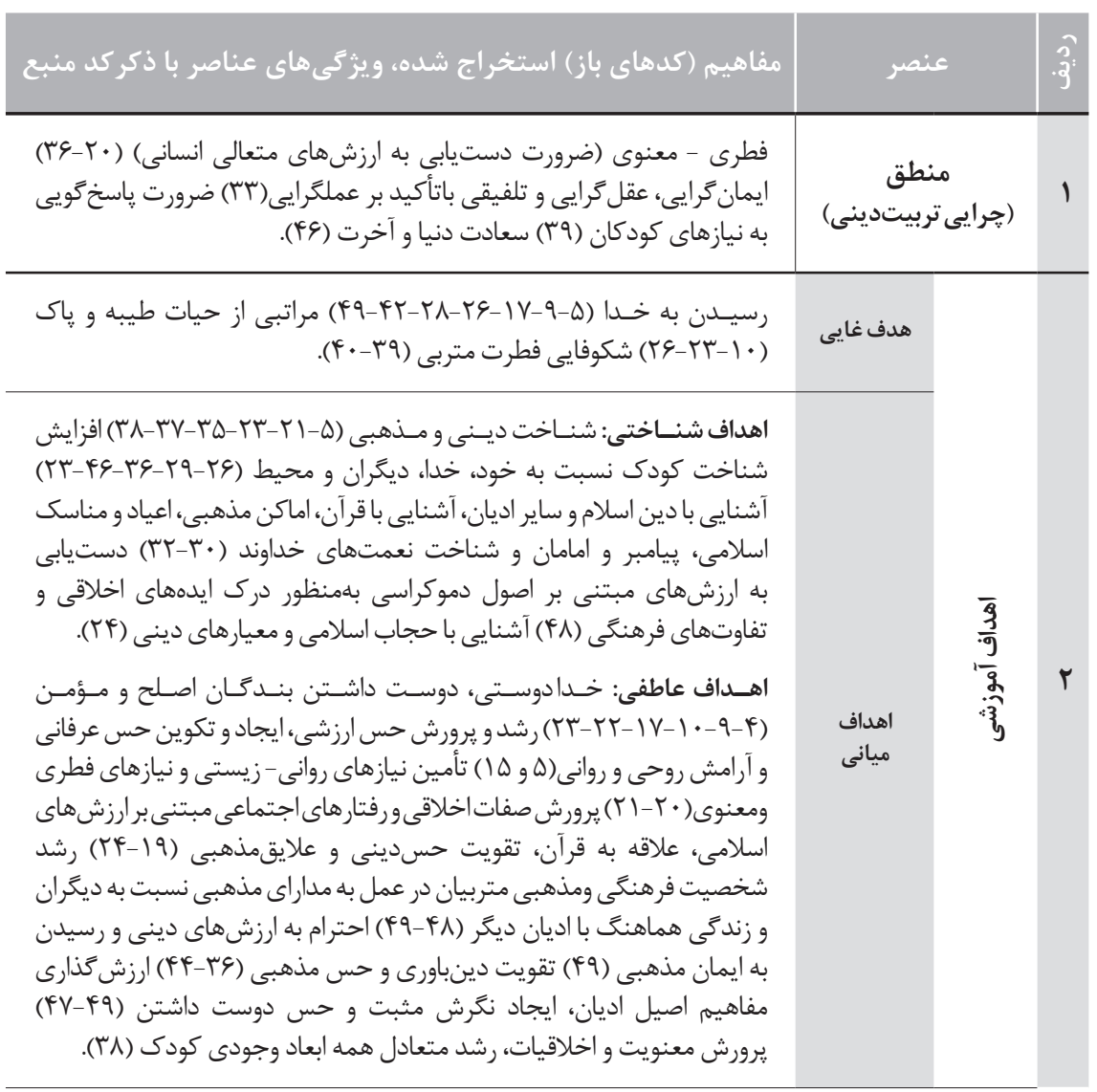




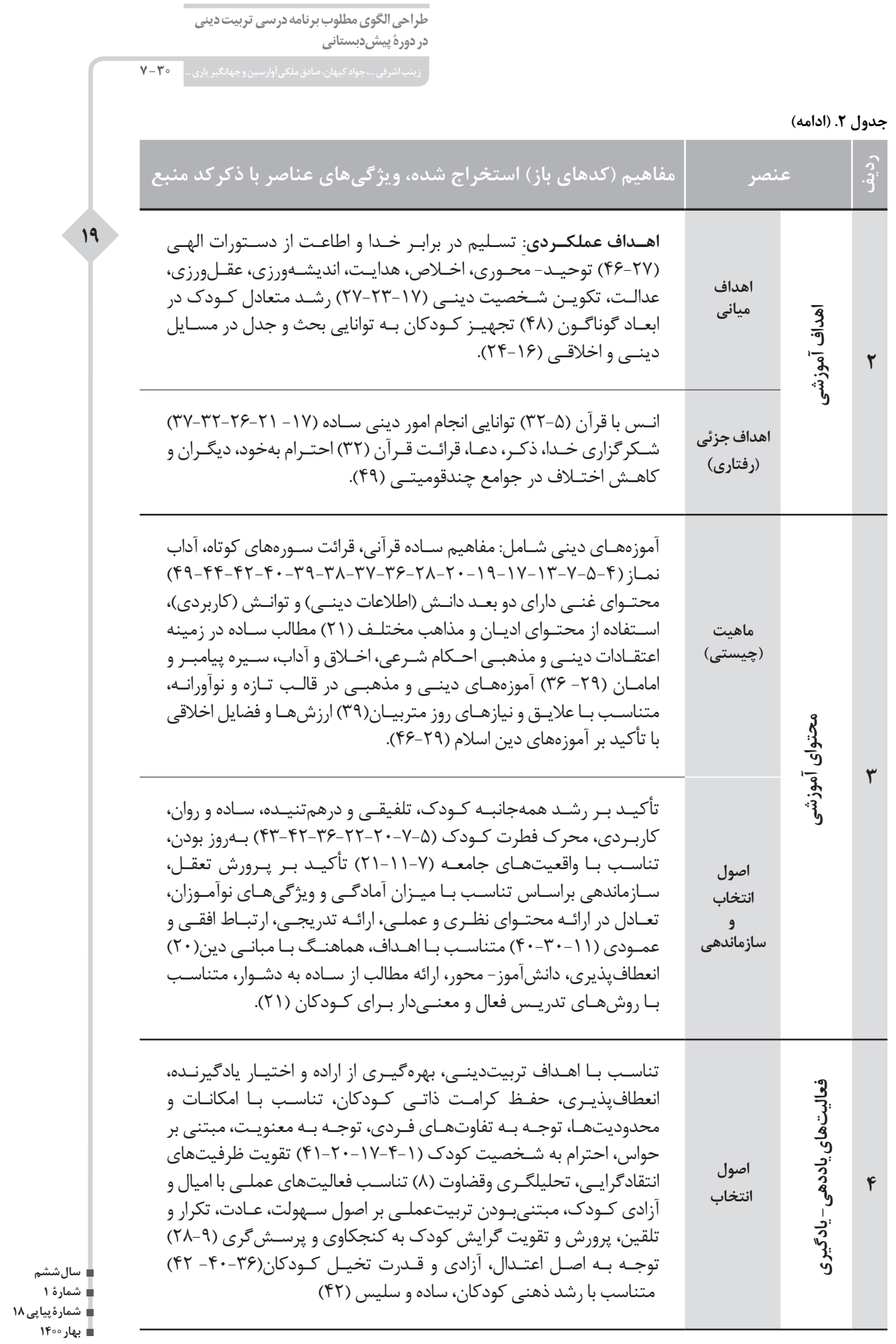


حدول r. (ادامه)

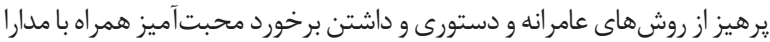

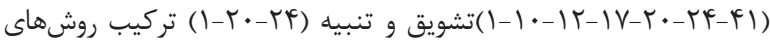

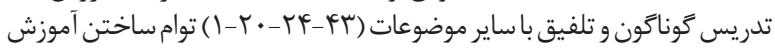

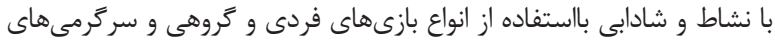

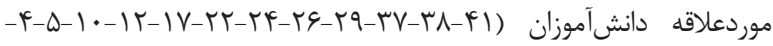
(F-Y

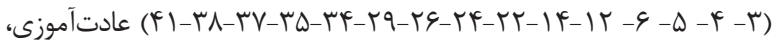

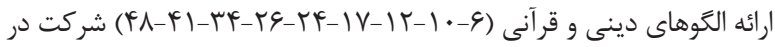

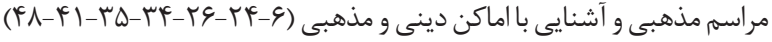

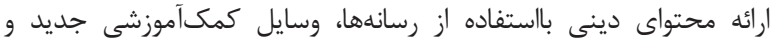

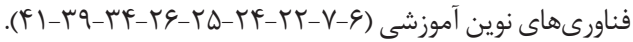

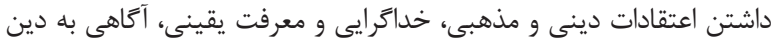

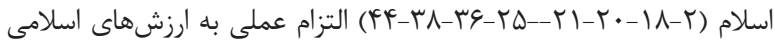

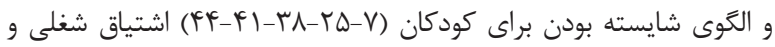

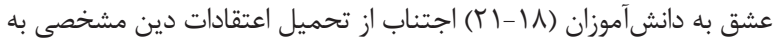

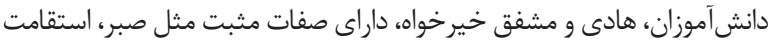

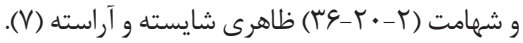

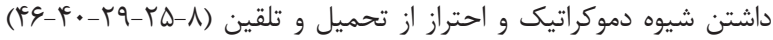

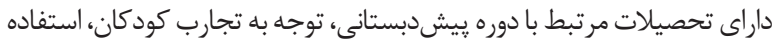

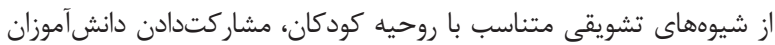

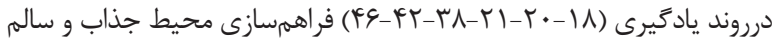

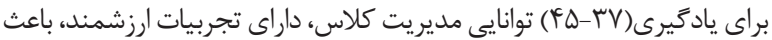

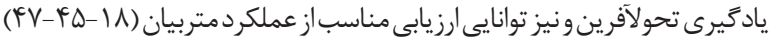

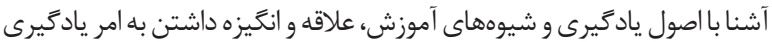

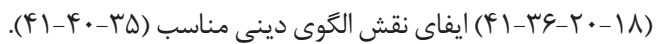

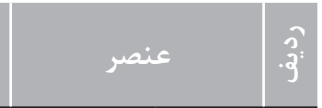

اعتقادى و إستى اخلاقى

روشها

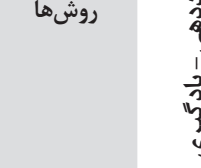

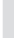


حدول r. (ادامه)

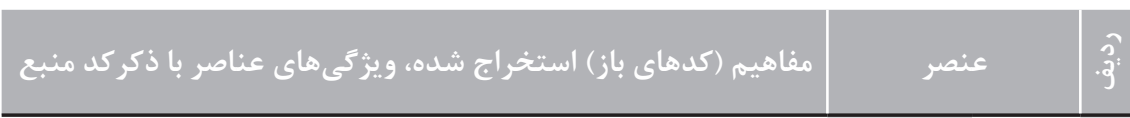

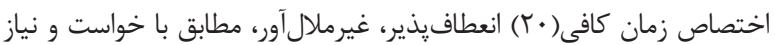

دانشآموزان (FY) (F)

جامع بودن، تنوع در روشها، توجه به اصل تكرار و تنوع إنها منبع دادهها در

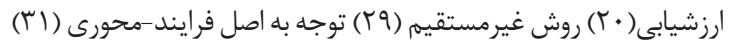

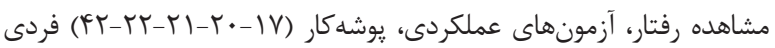

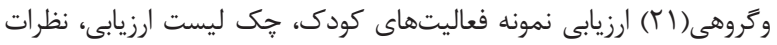

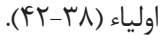

اصول ناظر

شيوهها

(ولياء

دادههاى جدول "، نيز نتايج مربوط به تجميع كدهاى باز و يالايش مجدد آنها بهمنظور

حذف كدهاى هميوش و ايجاد كدهاى محورى وكدهاى انتخابى را نشان مىدهد.

جدول س. يافتههاى مستخرج از فرايند كدكذارى محورى و منتخب

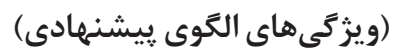

\begin{tabular}{|c|c|c|c|c|}
\hline كد باز & كد محورى & \multicolumn{2}{|c|}{ 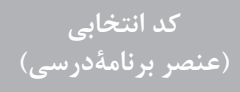 } & \\
\hline 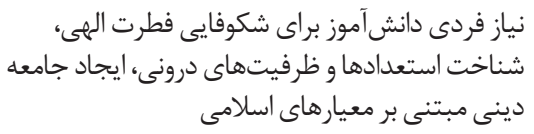 & 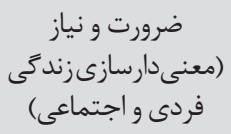 & \multicolumn{2}{|c|}{ (جرايى تربيت دينى) } & 1 \\
\hline ريبه ريدن به خداوند، دستيابى به مرتبهاى از حيات & هدف غايى يانهايى & \multirow{3}{*}{ سلسله مراتبى } & \multirow{3}{*}{$\frac{\overline{3}}{\frac{3}{9}}$} & \\
\hline 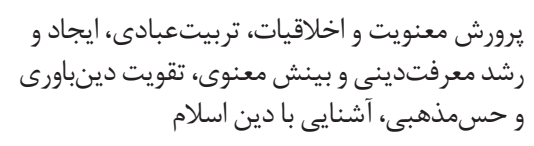 & اهداف ميانى & & & r \\
\hline 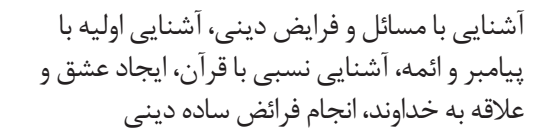 & 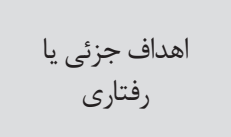 & & & \\
\hline
\end{tabular}


حدول ץ. (ادامه)

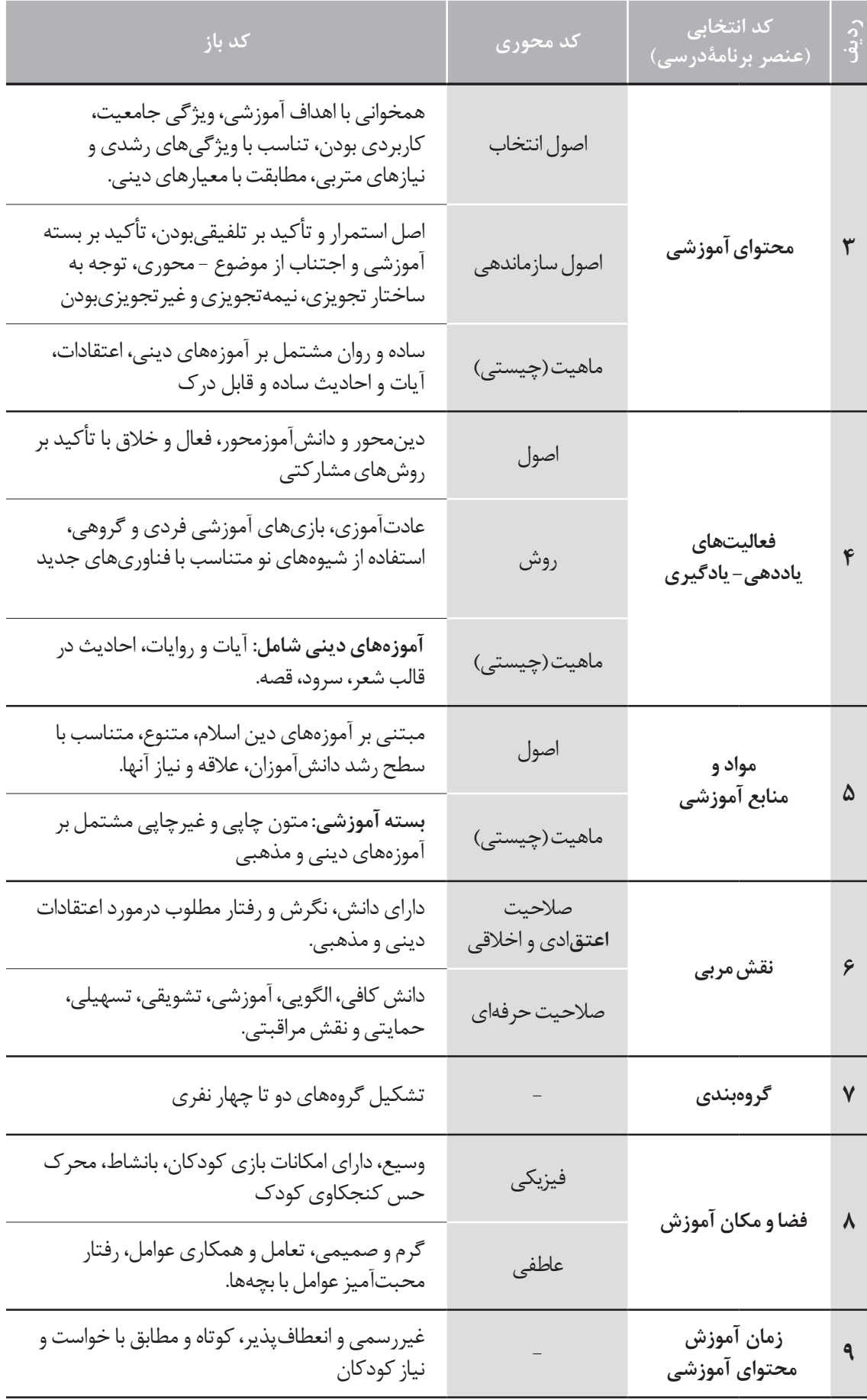


جدول r. (ادامه)

\begin{tabular}{|c|c|c|c|}
\hline كد باز & كد محورى & 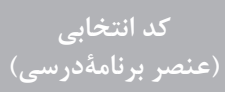 & 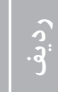 \\
\hline غيرمستقيم، فرايند-محورى اصل تنوع دادهها، روش & اصول ناظر & \multirow[b]{2}{*}{ ارزشيابى } & \\
\hline 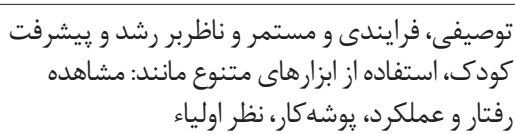 & شيوهها & & 1. \\
\hline
\end{tabular}

نمودار ( ()، الكوى ييشنهادى برنامdٔدرسى تربيتدينى دانش آموزان دوره ييشدبستانى مبتنى بر "رويكرد تار عنكبوتى اكِر) رابه تصوير كشيده است. اين الگو ارتباط موجود بين عناصر برنامأدرسى تربيتدينى را نشان داده و نقش محورى منطق و جرايى تربيتدينى را روشن مى كند. درنهايت مى توان دريافت، تربيتدينى يك كل منسجميافته از عناصر گوناگون است كه همانند تارهاى عنكبوت به هم وابستهاند و بهعبارتى لازم و ملزوم يكديكرند. در اين الخو، تركيب و هماهنكى مناسب آنها دركنار يكديخر، موفقيت برنامه درسى تربيتدينى را تضمين كرده و دانشآموزان را به مسير و هدف موردنظر نزديكتر مى كند.

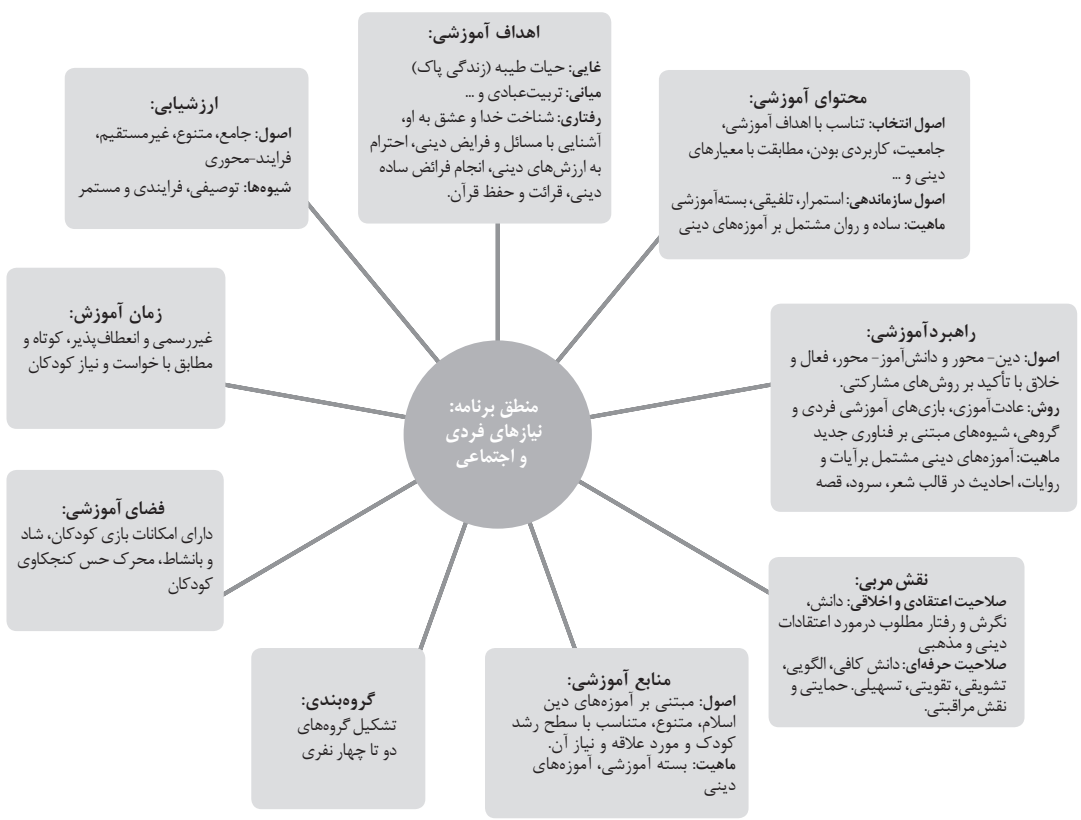




\section{بحث و نتيجلَّيرى}

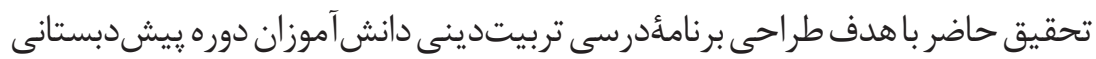

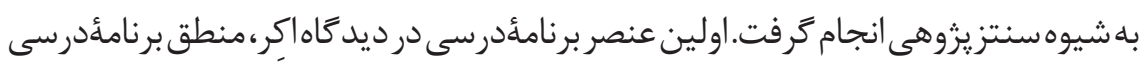
است كهبه קر ايى يادكيرى موضوع موردآموزشاشارهدارد (Akker,Fasoglio\&Mulder,2010).

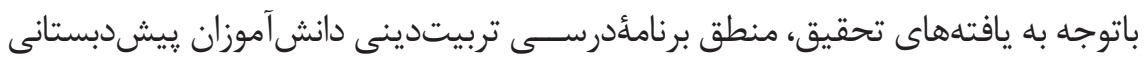

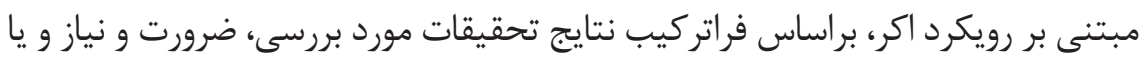

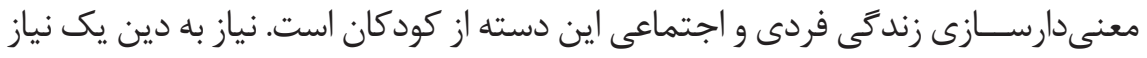

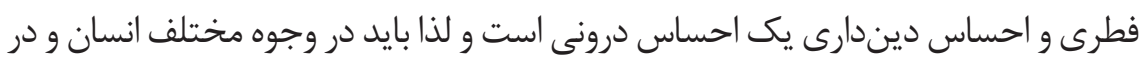

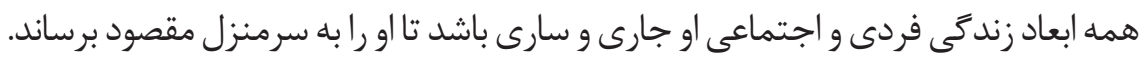

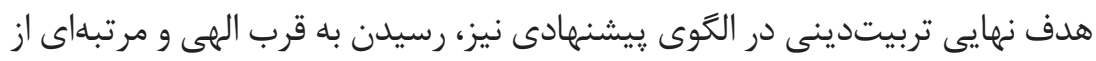

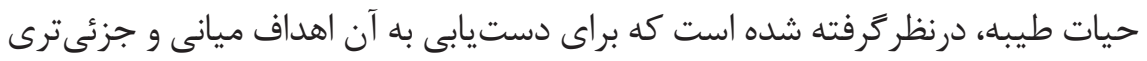

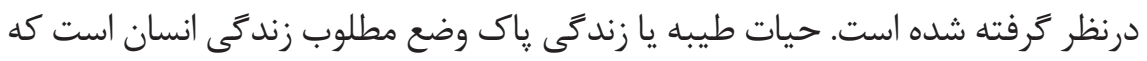

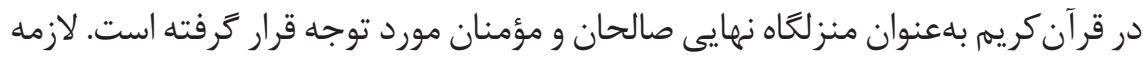

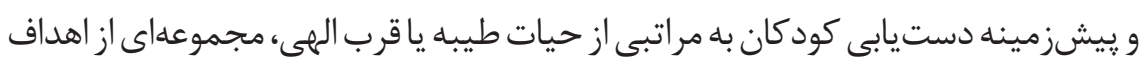

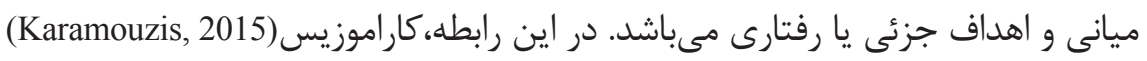

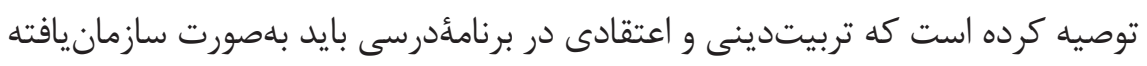

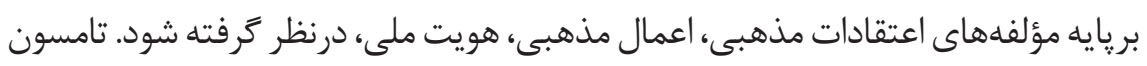
(Thompson, 2015)

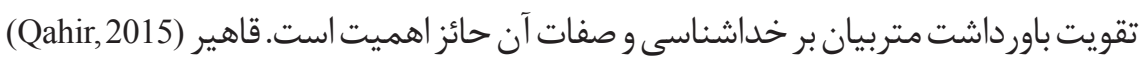

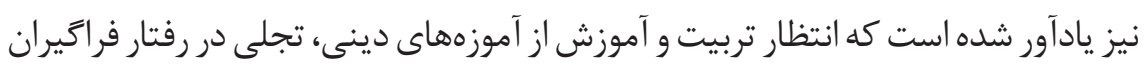

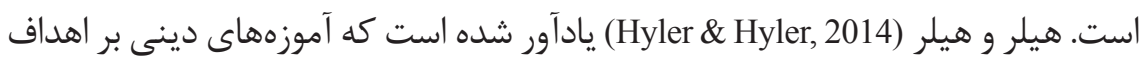

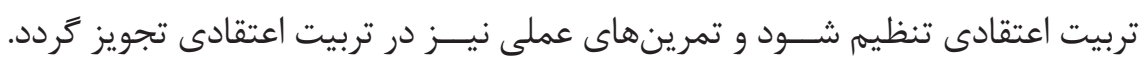

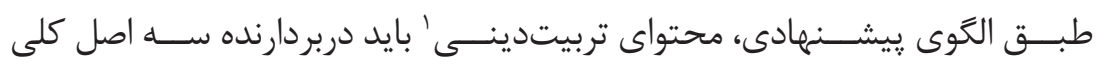

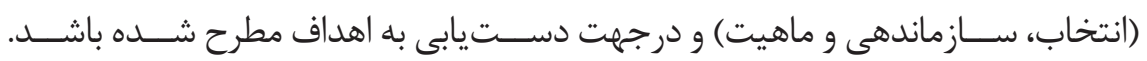

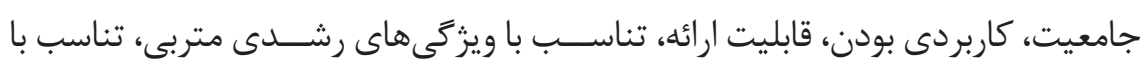

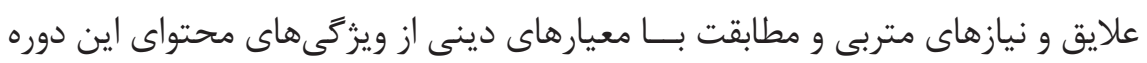

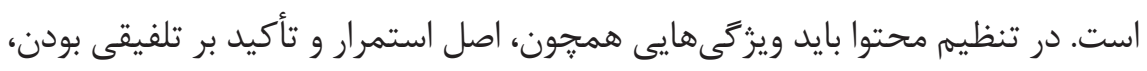


تأكيد بر بسته آموزشــى و اجتناب از كتاب محورى و موضوع محورى، توجه به ساختار تجويزى، نيمهتجويزى و غيرتجويزى بودن، سادكى و روان بودن آيات و احاديث، مدنظر قرار گَيرد. بديهى اســت كه اين محتوا بايد دربر گيرنده همه وجوه ارتباط كودك، يعنى رابطه با خود، خداوند، جهان هستى و انسانهاى ديخر باشد. باند

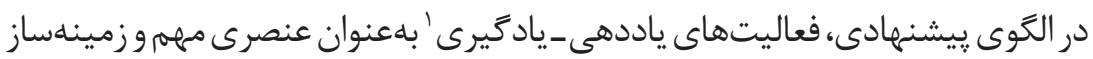
تحقق اهداف تربيتدينى، موردتأكيد قرارگرفته است. اين فعاليتها بايد براساس رويكرد معين (دانشآموز-محورى، و نيز فعال و خلاق با تأكيد بر روشهاى مشـــار كتى) انتخاب

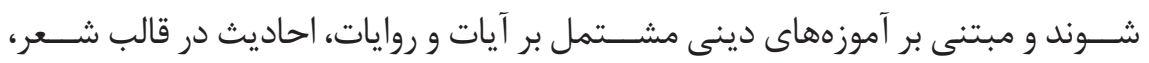
سرود، قصه باشـــند و از طريق عادتآموزى، بازىهاى آموزشى فردى وكروهى، استفاده

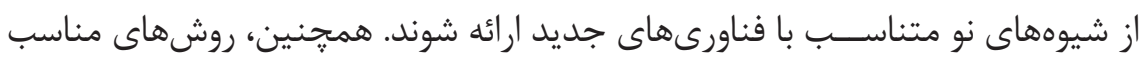

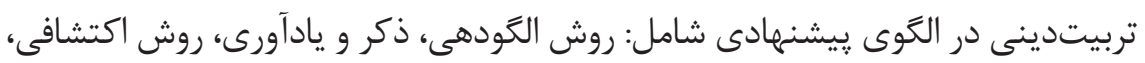

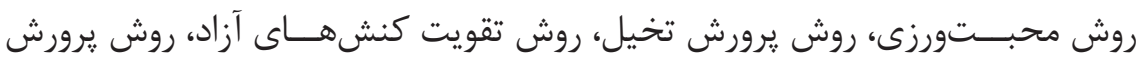
حواس رينج كانه و روش تلفيقى است. در تربيتدينى كـــودكان، محيط يادكيرى و فضاى آموزشــى بَ از نظر فيزيكى بايد داراى وســـت كافى بوده، شاد، بانشاط، متنوع و محرك حس كنجكاوى كود كان باشد و به جهارديوارى كلاس درس با جوى خشـــ و بىروح محصور نباشد. (كرمابى، ملكى، بهشتى و افهمى، Fqج (1) بر زيبا و شادابسازى فضاى فيزيكى و حتى عاطفى با استفاده

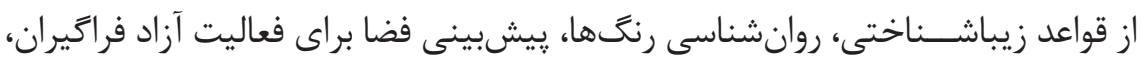
استفاده از تصاوير جهت غنى سازى محيط تأكيد كردهاند. در الخوى يـيشـــنهادى، مواد و منابع آموزشى بَ شامل بسته آموزشى متشكل از متون

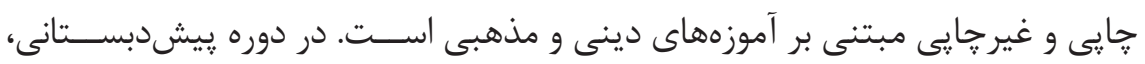
محتواى مشــــص و منحصر بهفردى براى تعليم آموزههاى دينى وجود ندارد و مى تواند

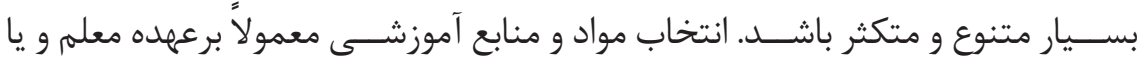

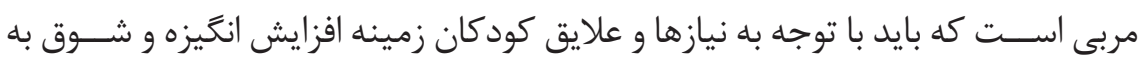
ياد گيرى آموزههاى دينى در فراخيران را ايجاد كند. استفاده از تصاوير گوناگون، مشاهده كردن دقيق اجزاى يك نوشته يا تصوير، تكميل كردن داستان، تركيب بعضى از مفاهيه، 
حل كردن جدول، رنَآميزى، ساختن كاردستى و... در ايجاد انگيزه بسيار مؤثر است. در حوزه تربيتدينى، نقش معلم و مربى حياتى بوده و همتراز شغل ييامبران درنظر گَرفته مىشود. در الكوى ييشنهادى نيز، معلم تربيتدينى بايد از دو ويزَّى مهرم، صلاحيت اعتقادى اخلاقى و صلاحيت حرفهاى برخوردار باشد. از مهمهترين خصوصيات مربى، التزام عملى وى به مسايل دينى، شناخت ويزگى ها وظرفيت كودك، هدايت فراخيران و دانستن شيوههاى تربيتدينى كودى است. همجنين، مربى بايد از صبر و حوصله برخوردار باشد مدئ و در ايجاد و تقويت فضاى اعتماد، دوستى و احترام متقابل بكوشد (على آبادى، مسعودى،

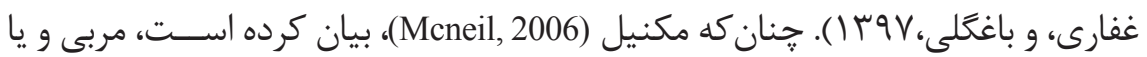
معلمى كه به تربيتدينى دانشآموزان مىيردازد، بايد خوشخلقترين و خوش خوترين معلمان باشد. اييلديزلر و كاركى (Yildizlar \& Kargi, 2010) نيز بيان كردهاند، بيشترين انتظار از مربيان اين اســت كه در مورد شغلشــان اطلاعات علمى و بهروز داشته باشند

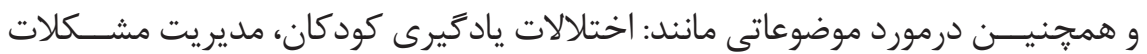
رفتارى كودكان و مديريت كلاس اطلاعات خاصى بلدست آورند. ماحصل تحقيقات نشان مى دهد كه معلم موفق در اين نوع تربيت معلمى است كه دركنار تدريس محتواى تدوين

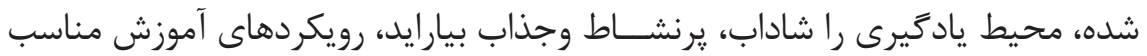
اتخاذ نموده و نقش هدايت زرى و تسهيل گرى داشته باشد.

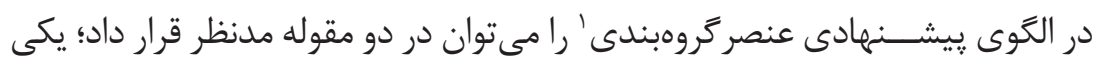
اهداف اجتماعى و ديخرى، اهداف آموزشى است كه در فرايند تربيتدينى مكمل يكديخر

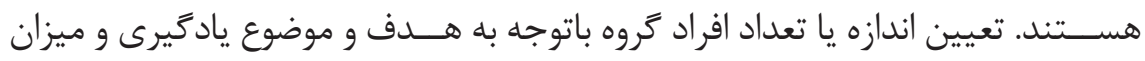

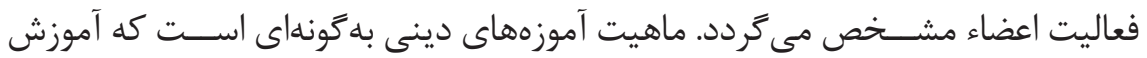
وياد كيرى مؤثر اكثر آنها مستلزم مشاركت و فعاليت گروهى دانش آموزان است.

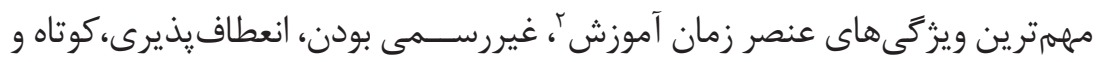
مطابقت با خواست و نياز متربيان مىباشد. وقتى كه از عنصر زمان در برنامأدرسى سخن

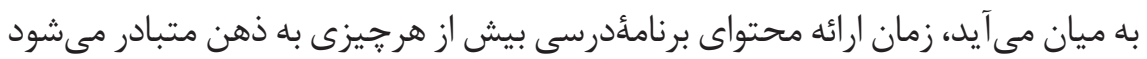

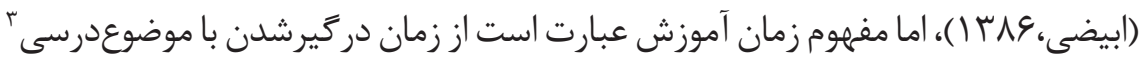
و فرصتى كه دانشآموزان به موضوع درسى توجه كرده و درفرايند يادگيرى شركت دارند. 


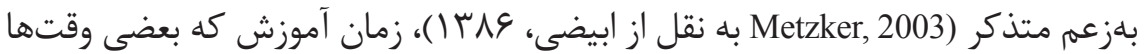

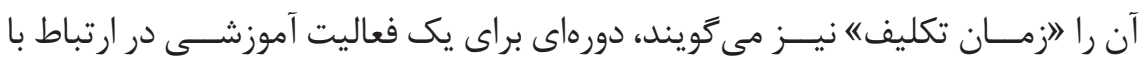
آمادگى دانشآموز براى يادگيرى است و منجر به يادگيرى واقعى مىشود. اين عنصر بايد تناســب لازم را با ساير عناصر برنامه داشته باشد و مديريت مناسبى براى استفاده از آن براى اثربخشتر كردن هرجه بيشتر فعاليتهاى تربيتدينى از سوى معلم صورت گيرد.

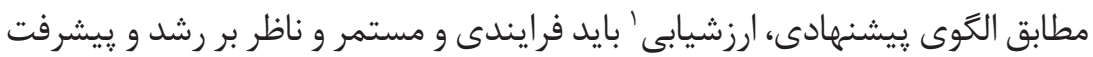
كودك، و با اســتفاده از ابزارهاى متتنوع مانند مشـــاهده رفتار و عملكرد، يوشه كار، نظر

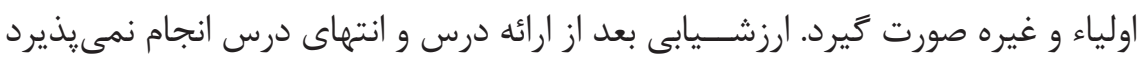
و بلهصورت فرايندى و از همان آغاز تدريس شـــروع شــده و درحين تدريس و يايان آن ادامه مى يابد. همجنـين، در ارزشــيابى بايد دانش آموز متتناسب با تلاشش ارزيابى شود. شيوههاى ارزشيابى در برنامةدرسى تعليم وتربيت دينى، بايد با تكيه بر ديدگاههاى نوين روانشناسى تربيتى تنظيم شود.

\section{يبشنهمادها}

براساس الكوى طراحى شده، يِيشنهاد مىشود كه در تربيتدينى كود كان ييش دبستانى،

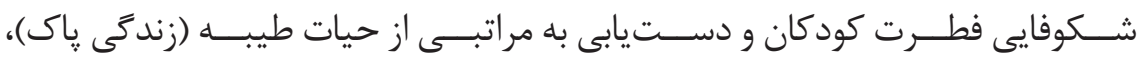
بهعنوان هدف غايى در نظرگرفته شود و محتواى آموزشى بايد مطابق با معيارهاى دينى و ويززَى هاى رشــدى و نيازهاى متربى بـــوده و ازطريق فعاليتهاى تدريس - يادَيرى متنوع توسط مربى شايسته و با اخلاق در اختيار نوآموز قرار گيرد. نقش مربى عمدتاً بايد هدايت كرى و تسهيل

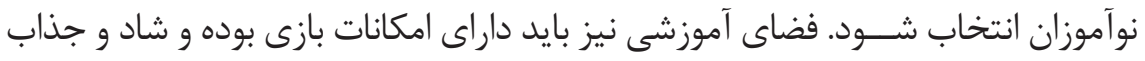
باشد. درنهايت ارزشيابى بايد باصورت غيرمستقيمى و مستمر انجام گيرد.

\section{تشكّر و قدردانى}

بدينوسيله از اساتيد محترم گروههاى آموزشى معارف و برنامهريزى درسى

دانشعاههاى كشور و مربيان محترم ييشدبستانى كه در انجام اين تحقيق همكارى لازم را با محققين حاضر داشتند، كمال تشكّر و قدردانى را داريم. 


\section{منابع}

قرآن مجيد.

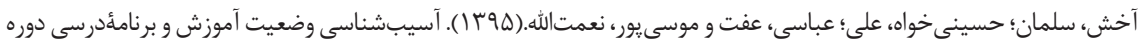

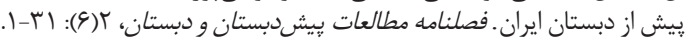

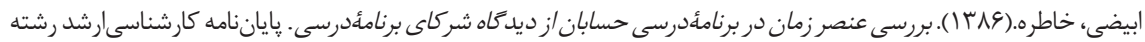

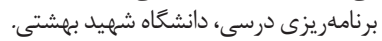

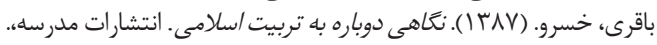

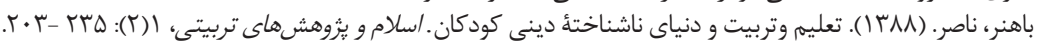

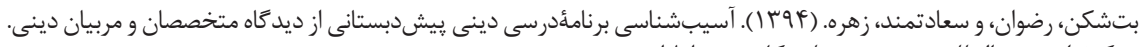

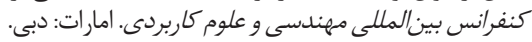

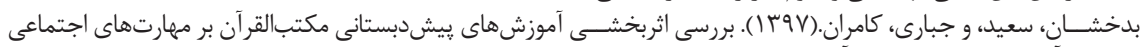

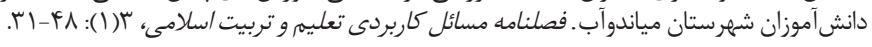

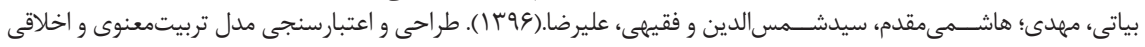

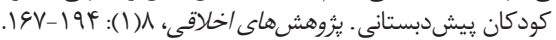

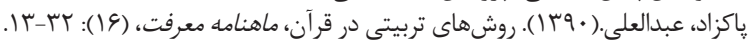

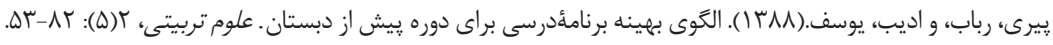

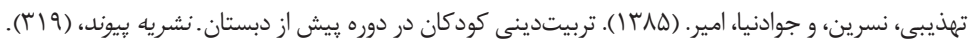

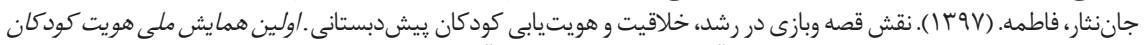

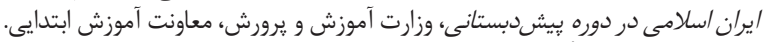

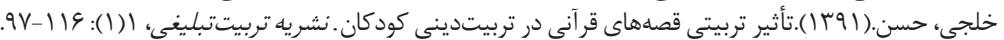

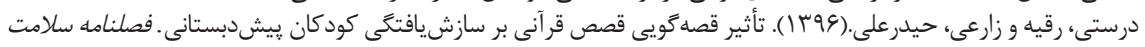

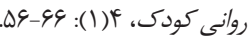

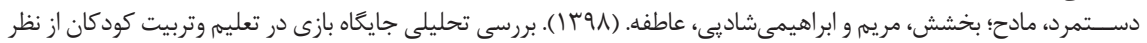

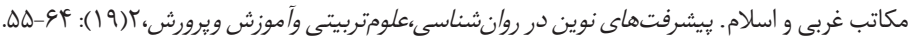

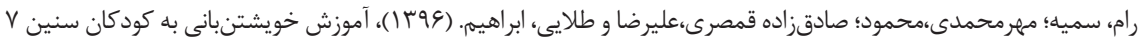

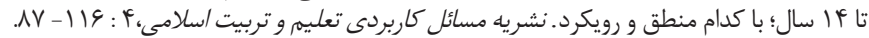

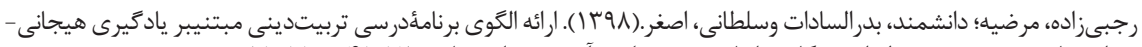

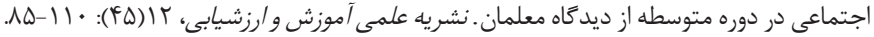

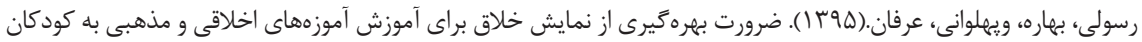

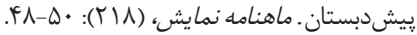

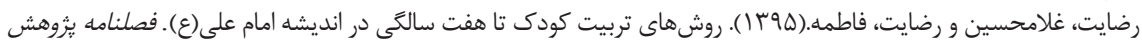

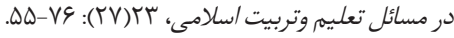

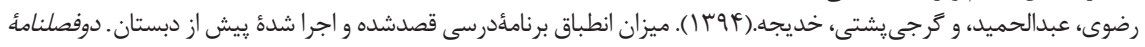

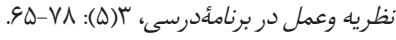

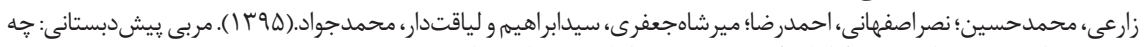

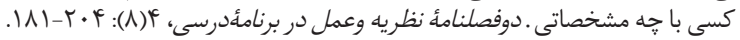

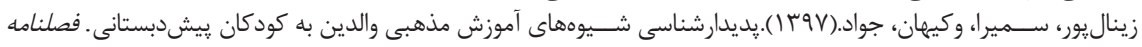

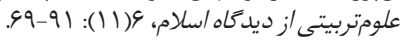

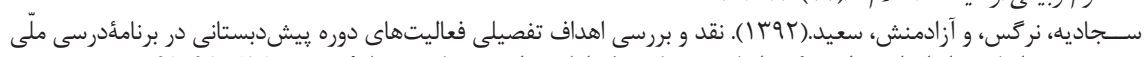

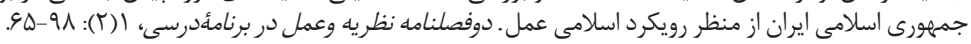

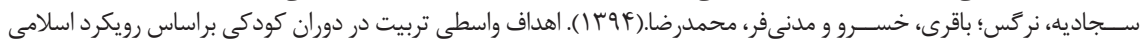

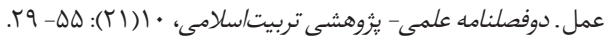

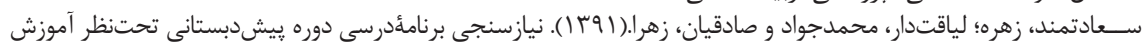

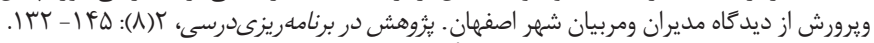

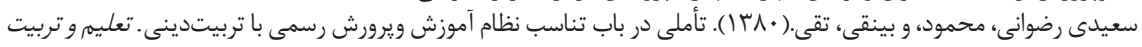

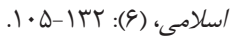

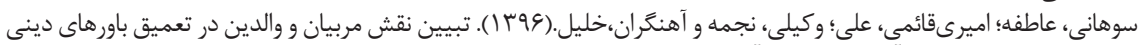

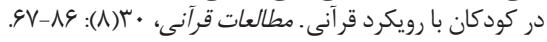

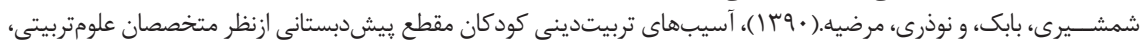

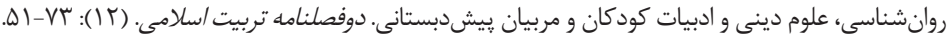

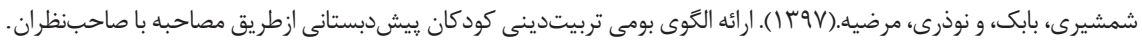




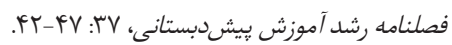

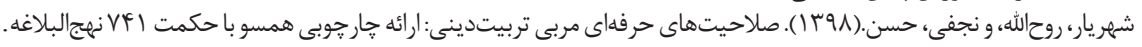

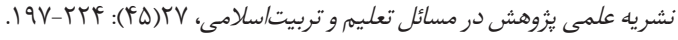

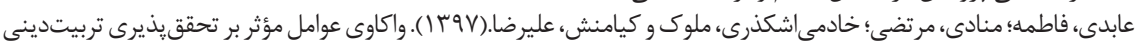

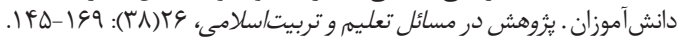

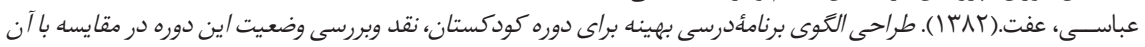

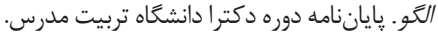

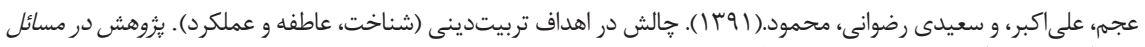

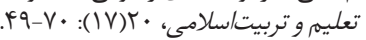

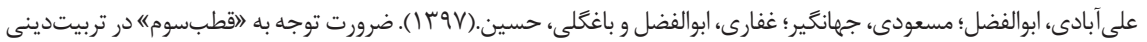

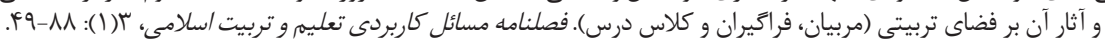

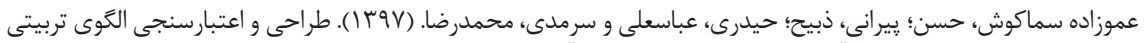

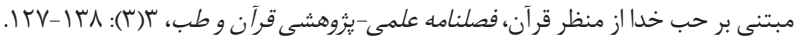

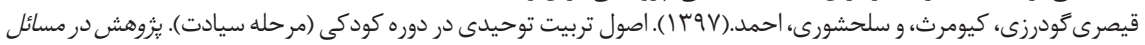

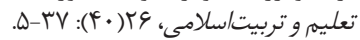

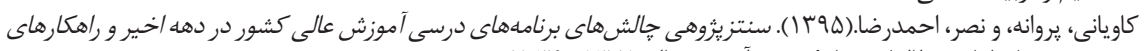

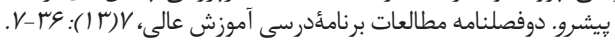

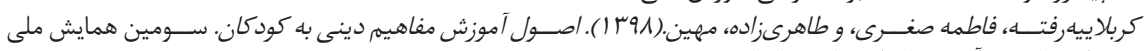

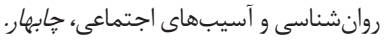

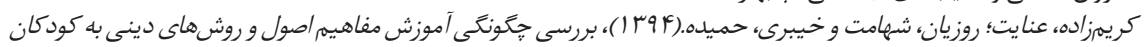

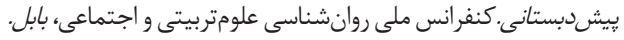

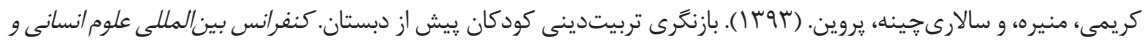

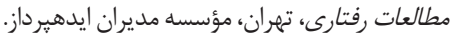

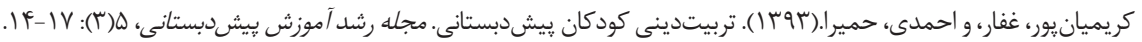

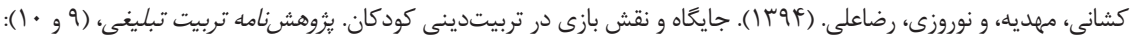
Fr-gF

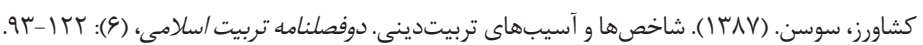

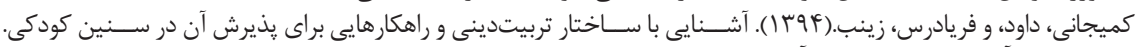

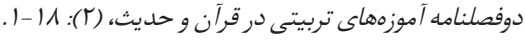

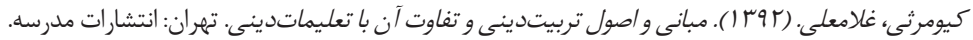

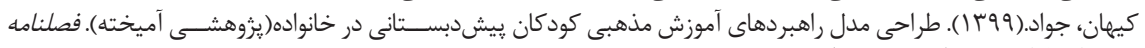

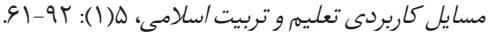

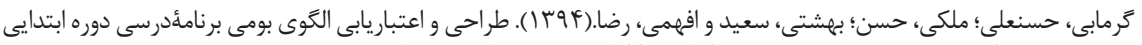

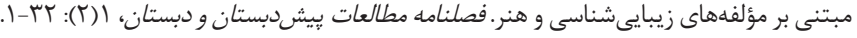

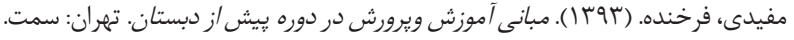

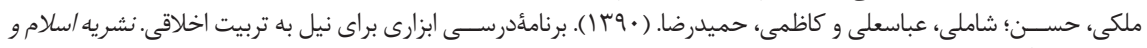

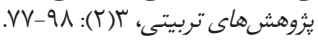

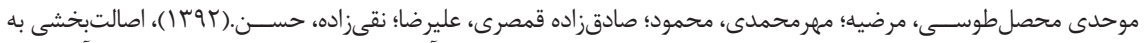

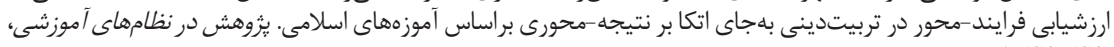

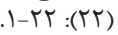

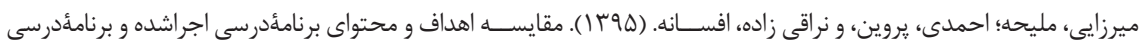

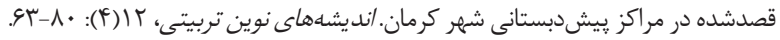

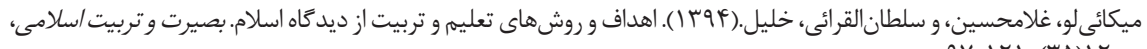

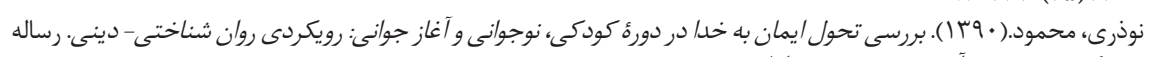

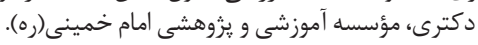

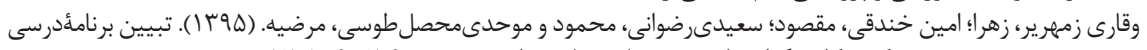

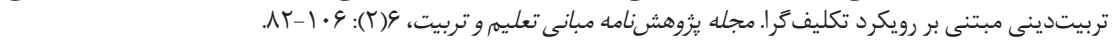

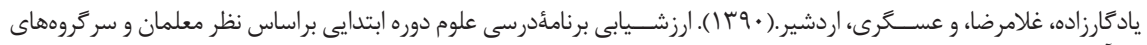

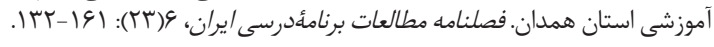


Akker, J. V. D, Fasoglio, D. \& Mulder, H. (2010). A curriculum perspective on plurilingual education. Council of Europe. Available at: www.coe.int/lang.

Akker, J. V. D. (2003). Curriculum perspectives: An introduction. In J. van den Akker, W. Kuiper \& U. Hameyer (Eds.), Curriculum landscapes and trends (pp. 1-10). Dordrecht: Kluwer Academic Publishers.

Aimin, L., \& Yan, C. (2011). A Case study of college english curriculum design under the social needs analysis. Studies in Literature and Language, 3(3): 1-5.

Aran, H,. \& Nayebkabir, M. (2018). Role of Parents in Religious and Social Education of Children, International Journal of Multicultural and Multireligious Understanding, 5(3): 180-191.

Barni, M. \& Mahdany, D. (2017). Al Ghazāli’s Thoughts on Islamic Education Curriculum. DINAMIKA ILMU.Vol. 17 No. 2, 2017. P-ISSN: 1411-3031; E-ISSN: 2442-9651. doi: http://dx.doi.org/10.21093/ di.v17i2.921.

Berkowitz, M. W. \& Bier, M. C. (2015). Research-based character education. Annals of the American Academy of Political and social Science: 591, 72-85.

Conroy, J. C., Lundie, D., Davis, R. A., Baumfield, V., Barnes, L. P., Gallagher, T., \& Wenell, K. J. (2015). Does religious education work? A multi-dimensional investigation. London: Bloomsbury.

De Roos, Simone, A. Iedema, J. \& Miedema, S. (2004). "Influence of Maternal Denomination, God Concepts, and Child Rearing Practices on Young Children's God Concepts." Journal for the Scientific Study of Religion, 43(4): 519-535.

Duman, G. (2014). Evaluation of Turkish preschool curriculum objectives in terms of values education. Procedia - Social and Behavioral Sciences.(152): 978 - 983.

Hashim, C. N. \& Langgulung. H. (2008). Islamic Religious Curriculum in Muslim Countries: The Experiences of Indonesia and Malaysia. Bulletin of Education \& Research., Vol. 30, No. 1, pp. 1-19.

Hewitt, T. W. (2006). Understanding and shaping curriculum: What we teach and why. Thousand Oaks: Sage Publications.

Hyler, E, \& Hyler, L. (2014). Lifestyles: Past, Present, Future, A unit to integrate Economics in the Junior High Classroom. This record was imported from ERIC on March 21.

Jafralie, S. \& Zaver, A. (2019). Teaching Religious Education: The Ethics and Religious Culture Program AS Case Study. International Research in Education, Vol. 5, Iss. 1, 2019, pp. 89-106.

Karamouz is Polikapos. (2015). The Greek Religion Innovation. In Sociology of Religion vol. 61 (2).89171.

Klein, M. F. (1980), “Curriculum as a Field of Study”, International Encyclopedia of Education. pp. 11421143.

Lemu. B. A. (2002). A Holistic Approach to Teaching Islam to Children: A Case Study in Northern Nigeria, Religious Education in Schools: Ideas and Experiences from around the World, Published in hardcopy by IARF, 2002; now at: iarf.net/resources/publications/Religious Education in Schools.pdf.

Marini, A. Safitri, D. \& Muda, I. (2018). Managing School Based on Character Building in The Context of Religious School Culture (Case in Indonesia).Journal of Social Studies Education Research: 9 (4), 274-294.

Mirascievaa, S. Petrovskia, V. \& Gjorgjevaa, E. P. (2011).Teaching in the religious education in the Republic of Macedonia today, Procedia Social and Behavioral Sciences: 15 (2011) 1404-1409.

Mcneil, D. (2006). Contemporary curriculum in thought and action. Hobokaen, Nj: John Wiley \& Sons, Inc.

Njoku, N. C. \& Njoku, D. I. (2015). Challenges to Effective Implementation of ChristianReligious Studies Curriculum: A Study of Secondary School Pupils in Ebonyi State of Nigeria, Journal of Education and Practice, 6(18): 176-180.

Qahir, K. (2015). Religion-baed conflict Resolution. In plural societies. Through provision of Education to the public.

Rahayu, W,. \& Munadi, M. (2019). Inculcation Religiosity in Preschoolers Local content curriculum, Jurnal Pendidikan Usia Dini, Volume 13 Edisi 2. http://journal.unj.ac.id/unj/index.php/jpud.

Thompson, R. (2015). Religion, Belief.Education and Discrimination. The Equal Righats review, Vol Fourtee (2015).

Yildizlar, M. \& Kargi, E. (2010). Preschool teachers, expectations and evaluations on the effects of inservice teacher education in the Turkish Republic of Northern Cyprus. Procedia Social and Behavioral Sciences, 2: 1951-1954. 